\title{
Dârulfünûn: Kadim Kavramların Terkibi
}

\author{
Darulfünun: Composition of Ancient Concepts
}

\author{
Hasan Sabri Çeliktaş* ${ }^{*}$
}

Öz

Bu çalışmanın konusu XIX. yüzyılda yüksek eğitim vermek üzere tarih sahnesine çıkan yeni kuruma isim olarak uygun görülen Dârulfünûn terkibidir. Osmanlı Devleti'nde XIX. yüzyılın ikinci çeyreğinde eğitim işlerinin "terbiyet-i âmme" kapsamında görüşülmesi ve bir takım planlamaların yapılması için Meclis-i Maârif-i Muvakkat kurulmuştur. Meclis, eğitim öğretim faaliyetlerinin üç kademeye ayrılması ve o zamanki eğitim kurumlarının ileri derecesinde olmak üzere yüksek eğitim verecek yeni bir kurumun açılması gerektiği yönünde devlete tavsiyede bulunmuş ve kuruma "Dârulfünûn" ismini uygun görmüştür. Dârulfünûn'un isimlendirilmesinde bir kısım tarihçi meseleyi önceden beri devam eden medrese eğitim anlayışı ile yeni oluşan eğitim anlayışı arasında karşıtııklar kurarak okumayı tercih etmektedir ki bu mesele çalışmamızın problemini oluşturmaktadır. Bu bağlamda çalışmanın iddiası ise isimlendirme meselesinde Dârulfünûn terkibindeki unsurların kadim ilim, kültür ve eğitim tarihinde bir karşılığının bulunduğu; yeni yapının medrese ve onun temsil ettiği eğitim anlayışının karşııında olmadığıdır. Tanımlanan problemin çözülmesine yönelik tarihî veri analiz yöntemi esas alınmıştı. Çalışmanın neticesinde Dârulfünûn terkibini oluşturan kelimelerin kadim ilim, kültür ve eğitim tarihimizde bir karşılığının bulunduğu; yeni yapının medrese ve onun temsil ettiği eğitim anlayışının karşııında olmadığı tespit edilmiştir.

\section{Anahtar Kelimeler}

Osmanlı yükseköğretimi, Meclis-i Maarif-i Muvakkat, Fünun Mektebi, Darulfünun (İstanbul Üniversitesi), medrese

\begin{abstract}
The subject of this study is the composition of Dârulfünûn, which is considered appropriate as a name for the new institution that emerged on the stage of history to provide higher education in the nineteenth century. In the second quarter of the nineteenth century in the Ottoman State, the Temporary Council of Education (Meclis-i Maârif-i Muvakkat) was established in order to discuss the educational affairs within the scope of public education (terbiyet-i âmme) and to carry out some planning. The Council advised the state that the activities of education and training should be divided into three levels and that a new higher education institution should be opened with the advanced level of the educational institutions at that time, and deemed the name "Darulfünun" appropriate for the institution. In the nomenclature of darulfünun, some historians prefer to read the matter by contrasting it with the pre-existing understanding of madrasah education and the newly formed understanding of education, which constitutes the problem of our study. In this context, the claim of the study is that the elements in the composition of Darulfünun in the nomenclature issue have a counterpart in the history of ancient science, culture and education; that the new structure is not opposed to the madrasah and the understanding of education it represents. In the study, the historical data analysis method was based on solving the identified problem. As a result of the study, it was determined that the words that constitute the composition of Darulfünun had a counterpart in the history of ancient science, culture and education; the new structure was not opposed to the madrasah and the understanding of education that it represented.
\end{abstract}

\section{Keywords}

Ottoman higher education, Temporary Council of Education, Fünun Mektebi (School of Sciences), Darulfünun (Istanbul University), madrasah

\footnotetext{
* Sorumlu Yazar: Hasan Sabri Çeliktaş (Dr. Öğr. Üyesi), Tekirdağ Namık Kemal Üniversitesi İlâhiyat Fakültesi, Felsefe ve Din Bilimleri Bölümü, Tekirdağ, Türkiye. E-posta: sabriceliktas@gmail.com ORCID: 0000-0001-5404-4824

Atıf: Hasan Sabri Celiktas, "Dârulfünûn: Kadim Kavramların Terkibi." darulfunun ilahiyat 31, 2 (2020): $215-245$.

https://doi.org/10.26650/di.2020.31.2.0020
} 


\section{Extended Summary}

In the second quarter of the nineteenth century in the Ottoman Empire, the Temporary Council of Education was established in order to discuss educational affairs within the scope of public education. The Council recommended that the education and training activities should be divided into three levels and that an educational institution called Dârulfünûn be established to provide higher education. In the background of the establishment of the new institution, there was a fünûn mektebi (school of sciences and arts) which was planned to be established to meet the education and training activities of non-Muslim subjects. At that time, non-Muslim subjects sent their children to Europe due to their educational institutions were not being at the desired level. Since the children who went there learned harmful things, it was determined that there was a problem against the state. In order to prevent this problem, The Sultan's approval was obtained for the opening of a fünun mektebi where only non-Muslim subjects would teach arithmetic sciences, industry, arts and professions, but the fate of this educational institution remained uncertain. The council, which was given the task of opening such an institution, prepared a report for the opening of a new educational institution named Dârulfünûn and this report was approved by the Sultan. Unlike fünûn mektebi, Dârulfünûn was conceived within the scope of terbiyet-i âmme (public education) not only to appeal to non-Muslim subjects but to all Ottoman subjects. At the same time, this new educational institution was conceived to encompass not only a certain group of sciences but also all sciences.

Until the nineteenth century, the need for secondary and high level civil education in the Ottoman State was met significantly by madrasahs, which had their own unique educational and administrative structure. In the mentioned period, education continued in madrasahs. In the naming of Dârulfünûn, some historians prefer to read the issue through the contrasts thought to exist between the understanding of education that had been continuing for a long time and the new understanding of education. This issue constitutes the problem of our study. The claim of the study is that the words dâr (house) and fünûn (sciences and arts) in the composition of Dârulfünûn were used in the history of ancient science, culture and education; and that the new structure was not opposed to the madrasah and the understanding of science it represents. As a result of our study, it was understood that the concepts that constitute the composition of Dârulfünûn have a counterpart in our history of ancient science, culture and education.

In history, the word dâr has been used as a key concept since the early periods of Islam to indicate a place where activities related to science, culture and education were carried out. The word fünûn has been a concept used to refer to the whole of literary, linguistic, religious, philosophical, aritmetic and natural sciences rather than a single branch of science from an early period. The composition of Dârulfünûn is seen in the reports of both the Temporary Council and other competent authorities as the source of the ulûm 
ve fünûn-l mütenevvia (sciences and various arts and sciences), which will ensure the development of the country and the advanced degree of schools at that time. In addition, this school has been recognized as a center where all sciences and arts will be taught for those who want to educate themselves from the Ottoman subjects and want to work in the state's staff.

Curriculums were established in different periods from 1863 to 1900, when education began in darulfünun. As mentioned in the analysis of the word fünûn, these curriculums cover a wide range of sciences ranging from literary sciences to religious sciences; from philosophical sciences to natural sciences; from aritmetic sciences to historical sciences. Among the sciences here, the religious sciences, the literary sciences, logic, philosophical sciences, aritmetic, geometry, astronomy and the like were also included in the madrasah education curriculum.

After all these explanations, it has been seen that the composition Dârulfünûn was neither far from the history of Islamic science, culture and education, nor was it a nomenclature that did not coincide with the understanding of education in the Ottoman State at that time. Choosing such a composition was of course, to indicate a different constitution. However, while making this choice, it was seen that there was no intent to oppose the madrasah and the sciences taught there or reject those sciences. It can be said that the naming of the new educational institution was made by evaluating the historical background in a good way.

The word fünûn has been used in books in which the classification of sciences is made, without making any religious, literary or natural distictions. The encompassing meaning in the word fünûn is connected with the diversity of sciences in the new higher education institution that was to be opened. Because this situation is clearly seen in the minutes of the Temporary Council of Education presented to the Meclis-i Vâlâ (Sublime Council), where the idea and naming of Dârulfünûn came to the agenda. The composition of Dârulfünûn in the minutes indicates a place and formation where kâffe-i ulûm ve fünûn (the whole of sciences and arts) would be taught. In this context, it is understood that the elements in the composition of Dârulfünûn have a counterpart in the history of ancient science, culture and education; that the new structure is not opposed to the madrasah and the understanding of science it represents; that the word fünûn in the composition was used not only for the Western sciences but also for the sciences of language sciences (ulûm-1 Arabiye), literary, logic, religious sciences and philosophical sciences. 


\section{Giriş}

Osmanlı Devleti’nde XIX. yüzyıl, dünya genelinde olduğu gibi çok yönlü değişimin yaşandığı önemli bir zaman dilimidir. Başta devlet yapısı olmak üzere toprak düzeni, adalet sistemi, askerî düzen gibi alanlarda, neticeleri itibariyle etkisini günümüzde de devam ettiren değişimler yaşanmıştır. Değişimin yaşandığı noktalardan birisi de diğer alanlardan bağımsız olması düşünülemeyen eğitim alanıdır. Eğitime yönelik XVIII. yüzyıldan itibaren dönemin beraberinde getirdiği ihtiyaç ve sorun alanlarına cevap niteliğinde bir takım isabetli adımlar atılmıştır. Atılan adımlar arasında devletin değişen yapısı gereği ortaya çıkan yetişmiş nitelikli insan ihtiyacını karşılamak üzere Mühendishâne-i Bahrî-i Hümâyun (1189/1775), Mühendishâne-i Berrî-i Hümâyun (1210/1795), Mekteb-i Tibbiye (1242/1827) ve Mekteb-i Harbiye (1250/1834) gibi eğitim kurumlarının yeni bir anlayışla açılması yer almaktadır. Adı geçen kurumlar daha çok askerî alana hitap etmektedir. Sivil alanda ise Mekteb-i Maârif-i Adliye ve Mekteb-i Ulûm-1 Edebiye (1255/1839) vb. eğitim kurumları açılmıştır. Yeni kurumların açılmasıyla birlikte artan eğitim faaliyetleriyle ilgili ön planlama yapacak bir yapıya gerek duyulmuş ve bu çerçevede öncelikli olarak Meclis-i Maârif-i Muvakkat (1261/1845) kurulmuştur. Meclisin ilk toplantılarında özellikle sivil alandaki eğitim öğretim faaliyetlerinin kademelere ayrılması gerektiği üzerinde durulmuştur. Üçlü yapı şeklinde düşünülen tahsil kademelerinin son basamağını oluşturmak üzere yüksek eğitim veren bir kurum açma fikri ortaya çıkmıştır. Meclisin önerisi ile ortaya çıan bu kurumun isimlendirmesi için Dârulfünûn terkibi uygun görülmüştür. Osmanlı Devleti'nde daha önce başka bir kuruma verilmeyen bu terkip, XIX. yüzyılda oluşan yeni eğitim anlayışı ile mevcut eğitim anlayışı arasındaki ilişki bakımından önem arz etmektedir. Önemine binaen yakın tarihimizin en köklü kurumlarından olan ve İstanbul Üniversitesi'nin öncüsü kabul edilen Dârulfünûn'un isimlendirilmesi meselesi çalışmamızın konusunu oluşturmaktadır.

Osmanlı Devleti'nde XIX. yüzyıla kadar orta ve yüksek seviyeli sivil eğitim alanındaki ihtiyaç önemli derecede medreseler tarafından karşılanmaktadır. Köklü bir geçmişe sahip olan medreselerin kendine has eğitim ve yönetim yapılanması vardır. Bahsi geçen dönemde Dârulfünûn isminde yeni bir kurum açılması gündeme geldiğinde medreselerde eğitim öğretime devam edilmektedir. Yüksek seviyeli eğitim vermesi düşünülen Dârulfünûn'un isimlendirilmesi hususunda bir kısım tarihçi meseleyi karşıtlıklar üzerinden okumayı tercih etmektedir. Karşıtlıklar önceden beri devam eden mevcut eğitim anlayışı ile yeni oluşum halindeki eğitim anlayışı arasında kurulmaktadır. Örneğin Engelhardt, Sultan Abdülmecid'in (18391861) yönlendirmesiyle terbiye-i umumiye programı hazırlamak üzere kurulan Meclis-i Muvakkat'ın kanun neşrettiğini ve bu kanunun "Dârulfünûn-1 Osmanî tesisini ve mekâtibin mümkün mertebe ulema yedinden alınıp hükümet idaresine 
verilmesini tazammun" ettiğini ileri sürmektedir. ${ }^{1}$ Temellendirilmeden ileri sürülen bu görüş, tarihi bilgi yanlışlığ içermenin yanında vakıa ile örtüşmeyen çarpıtma bir zannî yorumdan ibarettir. Öncelikli olarak Meclis-i Muvakkat'ın kanun çıkarma yetkisi yoktur. İkinci olarak Dârulfünûn kuruluş fikrinin sahibi olan Meclis'in yedi üyesinden başkan dâhil dördü ulemadan oluşmaktadır. Üçüncü olarak Meclis’in rapor olarak sunduğu Dârulfünûn ile ilgili belgelerin hiç birinde Engelhardt'ın bahsettiği ulemâ karşıtlığı veya bunu andıran bir ifade söz konusu değildir. ${ }^{2}$ Baltacıoğlu da yaptığı bir değerlendirmede şunları söylemektedir: “...Dârulfünûn'un menşei siyasidir: Hükümet "garplılaşmak" düsturuna tevfikan bir Dârulfünûn vücuda getirmek, bunu skolastiğin devamına, medresenin kuvvetine rağmen hayata sokmak istemişti...”3 Aynı şekilde Faik Reşit Unat “...batılılaşma yolunda olan devletin amme hizmetlerinde yer almalarını sağlamak ve medreselerin dışında dinî gelenek ve tesirlerden uzak modern bir üniversite [Dârulfünûn kastediliyor] kurulmak istenmişti." "diyerek yeni kurulan Dârulfünûn'u bir anlamda medresenin karşısında konumlandırmışlardır. Buradaki bakış açısını sürdüren Niyazi Berkes de yanlış bir tarihî değerlendirmeyle; Encümen-i Dâniş yerine "fenler evi" demek olan bir Dârulfünûn kurulması fikrinin, Cemiyet-i İlmiye-i Osmaniye'nin ve bunların çıkardığı Mecmua-y1 Fünûn dergisinin çevresinde doğduğunu ileri sürmektedir. Berkes, kurulacak üniversiteye Arapçada olduğu gibi "Külliye" ya da "Dârululûm" yerine "Dârulfünûn" adının verilmesinin Tahsin Efendi (1811-1881) ile Münif Efendi'nin (1830-1910) benimsediği “fencilik" görüşünün eseri olduğunu iddia etmektedir ${ }^{5}$ ki bu iddia da tarihi vakıaya uymamaktadır. Zira Dârulfünûn isminin geçtiği tespit edilen ilk belgelerin tarihi 1261/1845 yılına aittir. ${ }^{6}$ Cemiyet-i İlmiye-i Osmaniye'nin kuruluşu ise 14 Zilkade 1277/24 Mayıs 1861; Mecmua-i Fünûn dergisinin ilk sayısının yayımlanışı da Muharrem 1279/Temmuz 1862 tarihindedir. ${ }^{7}$ Berkes'in iddiasının aksine bunlardan çok öncesinde Dârulfünûn ismi konulmuş ve kurumun açılmasına yönelik çalışmalar başlatılmıştır.

1 E. Engelhard, Türkiye ve Tanzimât: Devlet-i Osmaniye'nin Tarih-i Islahâtı 1826-1882, Mütercimi: Ali Reşâd (İstanbul: Kanaat Kütüphanesi, 1327), 73-74.

$2 \mathrm{Bu}$ üç başlığ içeren bilgilere ait kaynaklar birinci bölümde verilmiştir.

3 İsmail Hakk1, Maârifde Bir Siyaset (İstanbul: Necm-i İstikbâl Matbaası, 1335), 65.

4 Faik Reşit Unat, Türkiye Eğitim Sisteminin Gelişmesine Tarihi Bir Bakış (Ankara: Milli Ĕgitim Basımevi, 1964), 49.

5 Niyazi Berkes, Türkiye'de Çağdaşlaşma (İstanbul: Doğu-Batı Yayınları, tarih yok), 232-235.

6 Bkz. İ.DH, 113/5710. 6 Zilkade 1261/6 Kasım 1845; İ.MSM, 25/656, lef 1. 12 Zilkade 1261/12 Kasim 1845.

7 Geniş bilgi için bkz. Abdullah Uçman, "Mecmûa-i Fünûn”, TDV İslâm Ansiklopedisi, https:// islamansiklopedisi.org.tr/mecmua-i-funun (29.10.2019); Ekmeleddin İhsanoğlu, "Cem'iyyet-i İlmiyye-i Osmâniyye", TDV İslâm Ansiklopedisi, https://islamansiklopedisi.org.tr/cemiyyet-iilmiyye-i-osmaniyye (29.10.2019). 
Konuyla ilgili olarak İhsanoğlu ise "dârulfünûn" isminin verilme sebeplerinin tam olarak açıklanamadığını belirterek "fenler evi" anlamındaki "Dârulfünûn"un o günün şartlarında medreseden ayrı bir müessese olduğunu "çarpıcı bir şekilde ortaya koymak için" bu ismin verilmiş olabileceğini ileri sürmektedir. ${ }^{8}$ Burada ihtimalli konuşan İhsanoğlu, daha sonraki bir çalışmasında ifadesindeki ihtimali kaldırarak şöyle demektedir: “Dârulfünûn'a 'fenler evi' manasına gelen bu adın verilmesi, o günün şartlarında medreseden ayrı bir müessese olduğunu çarpıcı bir şekilde ortaya koymak düşüncesinden doğmuştur." İhsanoğlu başka bir çalışmasında da "Tanzimat ricalinin, bu yeni eğitim kurumunun medrese ve orada okutulan ilimlerle ilgisinin olmaması hususunda bir tereddüdü yoktu."10 diyerek, Dârulfünûn'u medresenin karşısına konumlandırmışıtır. Bu kanaate ulaşırken de yeni kurumun ismini oluşturan kelimelerin tahlilinden hareket etmektedir. Buna göre fen kelimesinin XIX. yüzyılda müşahede, deney ve ispata dayalı bilimlere denilmeye başlandığına değinmektedir. Fünûn kelimesinin o dönemin literatüründe her zaman "ulûm ve fünûn" terkibinde kullanılırken "ulûm" kelimesinden ayırdedildiği ve Dârulfünûn terkibinde yalnız kullanıldığını; bunun da müessesenin daha çok "fen" kelimesiyle eş anlamlı olarak yeni tip Batı kaynaklı bilimlerin eğitiminin yapılacağı bir eğitim müessesesi şeklinde düşünüldüğünü iddia etmektedir. ${ }^{11}$ İhsanoğlu, Dârulfünûn üzerine yaptığ̀ son çalışmasında isimlendirme konusunda nihai hükmünü vermektedir. O, "dönemin devlet adamlarının "Dârulfünûn" ismini belirlerken, medreseyi çağrıştıracak "ilim" veya "ulûm" gibi kelimelerden kaçınarak yerine ev manasına gelen "dâr" ile fen kelimesinin çoğulu olan "fünûn" kelimelerinden oluşan "Dârulfünûn" tabirini

8 Ekmeleddin İhsanoğlu, "Darülfünûn Tarihçesine Giriş: İlk İki Teşebbüs”, Belleten (Ankara: Türk Tarih Kurumu Basımevi, 1990), LIV/210: 699. Belleten'de çıkan ve künyesine atıfta bulunulan bu makalenin birkaç paragrafında yapılan düzenlemelerle başka bir yerde aynen yayımlanmıştır. Ancak Belleten'de çıkan ile aynısı olmasına karşın söz konusu yazıda makaleye hiçbir şekilde atıfta bulunulmamıştır. Karşılaştırınız: Ekmeleddin İhsanoğlu, "Tanzimat Döneminde İstanbul'da Dârulfünûn Kurma Teşebbüsleri”, 150. Yılında Tanzimat, Yayına Hazırlayan: Hakkı Dursun Yıldız (Ankara: Türk Tarih Kurumu Yayınları, 1992), 397-439. Burada yazının ilk şeklinin yine İhsanoğlu tarafından Türk Tarih Kurumu'nun 31 Ekim-3 Kasım 1989 tarihinde Ankara'da düzenlenen Tanzimat'in 150. Yıldönümü Uluslararası Sempozyumu'nda sunulmuş olduğu dipnotta verilmesine karşın Belleten'de 1990'da çıkan makalede bu durumdan hiç söz edilmemiştir.

9 Ekmeleddin İhsanoğlu, "Dârulfünûn: Mefhum ve Müessese Olarak Sultan II. Abdülhamid Dönemine Kadar Gelişmesi”, Sultan II. Abdülhamid ve Devri Semineri: 27-29 Mayls 1992 Bildiriler (İstanbul: Edebiyat Fakültesi Basımevi, 1994), 173-190.

10 Ekmeleddin İhsanoğlu, Dârülfünûn: Osmanlı'da Kültürel Modernleşmenin Odağı (İstanbul: İslâm Tarih, Sanat ve Kültür Araştırma Merkezi, 2010), I: 79.

11 İhsanoğlu, "Darülfünûn Tarihçesine Giriş: İlk İki Teşebbüs", 699; İhsanoğlu, Dârülfünûn: Osmanlı'da Kültürel Modernleşmenin Odağı, 80. Bu iddia Zengin tarafından da İhsanoğlu'na atıfla tekrarlanmaktadır. Bkz. Zeki Salih Zengin, Medreseden Dârulfünûna Türkiye'de Yüksek Din Eğitimi, (İstanbul: Çamlıca Yayınları, 2011), 30-31. 
türettiklerini; her iki kurum arasındaki temel farkın, ilk andan itibaren kesin olarak belirlenmesini temin etmek istediklerini" ileri sürmektedir. ${ }^{12}$

Yeni kurulan Dârulfünûn'un medrese ve orada okutulan ilimlerle alakasının olmadığını ileri sürmek, kendi içinde birkaç problem barındırmaktadır. Bunlardan ilki, Dârulfünûn'un medresenin alternatifi ve onun yerine açılan bir kurum olduğu yaklaşımıdır. Arşiv belgelerinde görüleceği üzere ne kuruluş arefesinde ne de derslerin başladığı dönemde böylesi bir yaklaşım söz konusu değildir. İkinci olarak medrese kurumunun algılanışı noktasındadır. Medreseye salt 'İslâmî ilimlerin' öğretildiği bir kurum olarak bakılmakta; medresenin dil ilimlerinden usûl ve hikmet ilimlerine geniş kapsamlı müfredatına dikkat edilmemektedir. Üçüncü problem ise ikincisiyle ilgili olarak yeni eğitim kurumunda okutulan ilimlerin medrese ilimleriyle ilgisinin olmaması meselesidir ki bu da medrese yüksek eğitim anlayışının algılanışından kaynaklanmaktadır. Medrese yüksek eğitim anlayışındaki temel ögeler sağlam bir dil, edebiyat, mantık, hikmet ve usul eğitimi üzerine oturtulmaktadır.

Verilen örneklerde Dârulfünûn'un isimlendirilmesi meselesinin diyalektik bir nazarla açıklanmaya çalışıldığı görülmektedir. Dolayısıyla yeni açılan yüksek eğitim kurumuna "Dârulfünûn" terkibinin uygun görülmesinde bir kısım tarihçi tarafından kurumun, medrese karşısında konumlandırılma meselesi çalışmamızın problemini oluşturmaktadır. Bu bağlamda çalışmanın iddiası ise isimlendirme meselesinde Dârulfünûn terkibindeki unsurların kadim ilim, kültür ve eğitim tarihinde bir karşıllğıının bulunduğu; yeni yapının medrese ve onun temsil ettiği eğitim anlayışının karşısında olmadığıdır. Bunu ifade ederken Dârulfünûn'un tamamen medrese eğitim anlayışını barındırdığı ve bu anlayışı sürdürdügü kastedilmemektedir. Medrese eğitim anlayışının Dârulfünûn'daki izlerinin takip edilmesi, üzerinde ayrıca düşünülmesi gereken bir iddia ve çalışma konusudur.

Çalışmamızda tanımlanan problemin çözülmesine yönelik tarihî veri analiz yöntemi esas alınmıştır. Bu çerçevede arşiv belgeleri, mazbatalar ve dönemin gazeteleri gibi birincil kaynaklardan yararlanılarak Dârulfünûn fikrinin nasıl ortaya çıktığı ve ilgili belgelerde Dârulfünûn'un nasıl tanımlandığı tespit edilmeye çalışılmıştır. Daha sonra Dârulfünûn terkibini oluşturan kelimelerin tahlili yapılmış ve bunların ilim, kültür ve eğitim tarihindeki karşı1ıkları ortaya konulmuştur.

Dârulfünûn tarihi hakkında önemli çalışmalar olmakla birlikte kurumun isimlendirilmesi üzerine müstakil bir çalışma bulunmamaktadır. Dolayısıyla

12 İhsanoğlu, Darülfünun: Osmanlı'da Kültürel Modernleşmenin Odağı, I: 352. Buradaki yaklaşımların bir benzerini Adıvar'da da görmek mümkündür: "Bizde ise...müsbet ilimlere, belki medrese ulemâsının gönlünü hoş etmek için, fen tâbiri layık görülmüş..." bkz. Abdülhak Adnan Adıvar, Osmanlı Türklerinde İlim, İstanbul Maarif Matbaası, 1943, s. 198. 
bu çalışmada Dârulfünûn'un isimlendirilmesi meselesine eğilerek Osmanlı eğitim tarihinin en mühim kurumlarından birisinin ve günümüzdeki İstanbul Üniversitesi'nin öncüsü olan kurumun tarih sahnesinde nasıl bir bakış açısıyla yer aldığını ve arşiv belgelerinden hareketle Dârulfünûn terkibine yüklenen anlamın ne olduğunu ortaya çıkarmak hedeflenmektedir. Bu açıdan çalışmamızın yüksek eğitim tarihine önemli bir katkı sunması umulmaktadır.

\section{Yeni Bir Yüksek Eğitim Fikrinin Ortaya Çıkışı: Fünûn Mektebi}

Dârulfünûn'un kuruluşu ile ilgili bilgilerin genellikle 22 Safer 1262/19 Şubat 1846 tarihli Meclis-i Vâlâ mazbatasına ${ }^{13}$ ve buradaki bilgilerin ilan edildiği Takvim-i Vekâyi'de yer alan habere ${ }^{14}$ dayandırıldığı görülmektedir. ${ }^{15}$ Bu bilgilerde mesele Meclis-i Maârif-i Muvakkat'ın son mazbatalarından hareketle ele alınmakla birlikte söz konusu meclisin eğitim öğretim meseleleriyle ilgili ilk mazbatalarına yeterince değinilmemektedir. Dolayısıyla Dârulfünûn fikrinin ve isminin ortaya nasıl çıktığ1 hususu kapalı kaldığı için bu başlık altında Dârulfünûn'a giden süreci takip etmek adına Meclis-i Maârif-i Muvakkat'ın ilk mazbataları yakından incelenmiştir.

Sultan Abdülmecid Han, 4 Muharrem 1261/13 Ocak 1845'te Sadrazam'1 ve Meclis-i Vâlâ'yı ziyareti esnasında okuduğu hatt-1 hümâyûnda eğitim öğretim işlerinin önemine dikkat çekmektedir. ${ }^{16}$ Osmanlı eğitim tarihinde önemli bir yeri olan bu hatt-1 hümâyûnda, bütün Osmanlı tebaasından din ve dünya açısından cehaletin giderilmesi yönünde bir takım adımlar atılması istenmektedir. Atılacak adımlar arasında ulûm ve fünûnun kaynağı; sanayinin me'hazı olarak görülen yeni eğitim kurumlarının vücuda getirilmesi yer almaktadır. Devletin yapacağı öncelikli işler arasında tesisi öngörülen eğitim kurumlarının, ülkenin uygun yerlerinde açılmasıyla "terbiyet-i âmmenin" yerine getirileceği ifade edilmektedir.

Meclis-i Vâlâ'ya hitaben okunan hatt-1 hümâyûnda iki husus dikkati çekmektedir. İlki, eğitim öğretim işlerinde bütün Osmanlı tebaasının zikredilmesidir. Bundan önce Osmanlı tebaasındaki Müslim ve gayrimüslimler, adalet işlerinde olduğu gibi eğitim işlerinde de kendi milletlerinin dinine göre amel etmekteydiler. Devlet,

13 İ. DH, 129/6634. 22 Safer 1262/19 Şubat 1846 tarihli Meclis-i Vâlâ Mazbatas1.

14 Takvim-i Vekâyi, 27 Receb 1262/21 Temmuz 1846, say1 303: 2, sütun 1.

15 İhsanoğlu, "Dârulfünûn Tarihçesine Giriş: İlk İki Teşebbüs", 700-702; İhsanoğlu, Darülfünun: Osmanlı'da Kültürel Modernleşmenin Odă̆, I: 86.

16 Bkz. AMD-d, 374/17. Burada fermanın 4 Muharrem 1261/13 Ocak 1845 tarihinde meclise hitaben okunduğu kayıtlıdır. Sultan'ın hatt-1 hümâyûnundan sonra 8 Muharrem 1261/17 Ocak 1845 'te Bâbıâlî'den Padişaha konu ile ilgili bir takrir sunulmuştur. Bkz. AMD-d, 374/17-18. Ayrıca ferman şurada da yayımlanmıştır. Bkz. Takvim-i Vekâyi, 12 Muharrem 1261/21 Ocak 1845, say1 280: 1, sütun 1-2. 
gayrimüslim tebaasının eğitim işlerine karışmamaktaydı. Hatt-1 hümâyûn vesilesi ile gayrimüslim tebaanın eğitim işlerinin devletin gündemine alınması istenmektedir. İkinci önemli husus ise yeni eğitim kurumlarının açılması meselesidir. Hatt-1 hümâyûnda memleketteki askerî düzenlemelerin başarılı bir şekilde devam ettiğine işaret edilmektedir. Askerî düzenlemeler arasında Mühendishâne, Mekteb-i Tıbbiye ve Mekteb-i Harbiye'nin açılması yer almaktadır. Bunların askerî karakter taşıması hasebiyle "terbiyet-i âmme" vurgusu yapılarak sivil alanda da herkesin gidebileceği yeni eğitim kurumlarının tesis edilmesi üzerinde durulmaktadır. Ayrıca önceden daha çok vakıflar eliyle yürütülen "terbiyet-i âmme" alanındaki faaliyetleri, bu dönemde siyasi yapıdaki değişimin de belki bir gereği olarak artık devletin kendi uhdesine alacağı yeni bir döneme girileceğinin emareleri olarak görülebilmektedir.

Hatt-1 hümâyûnun îradından kısa bir süre sonra Meclis-i Vâlâ'da konu üzerine yapılan toplantı neticesinde kaleme alınan mazbatada mevcut eğitim kurumları hakkında bir nizamnâme hazırlanması tartışılmıştır. ${ }^{17}$ Eğitim kurumlarının düzenlenmesinden yegâne maksadın, Osmanlı tebaasından cehaletin giderilmesi; ulûm ve fünûn-1 nâfianın tahsili; faziletlerin, edeplerin ve yeterli bilgilerin kazandırılması olduğu özellikle belirtilmektedir. ${ }^{18}$ Tartışmalar neticesinde eğitim kurumlarının tanzim işlerini planlamak için Meclis-i Maârif-i Muvakkat'ın kurulması kararlaştırılmıştır. Meclisin üyelerinin kimlerden oluşacağı da belirtilmiştir. Başkanlığını ulemadan Abdülkadir Beyefendi'nin yapacağı meclisin üyeleri, Osmanlı devlet yönetiminin üç önemli ayağından yani ilmiye, seyfiye ve kalemiye mensupları arasından seçilmiştir. ${ }^{19}$

Meclis-i Vâlâ, eğitim işlerini görüşmek üzere kurulan Meclis-i Maârif-i Muvakkat'ın müzakere edeceği konuları da beş madde halinde önceden belirlemiş̧ir. Bu maddeler aynı zamanda Osmanlı Devleti'nde XIX. yüzyılın ilk yarısındaki eğitim ile ilgili meselelerin başlıcalarına da işaret etmektedir. ${ }^{20}$

17 İ.MSM, 25/653; MVL.d, 470/10. 11 Safer 1261/19 Şubat 1845.

18 Konu mazbatada şu şekilde ifade edilmektedir: “...tanzim-i mekâtibden murâd-1 mücerred aceze-i nâs ve teba evlatlarının izâle-i cehele ile istihsâl-i ulûm ve fünûn-1 nâfia ve iktisâb-1 fezâil ve âdâb ve malumât-1 kâfiye içün olduğu muhassenâtını herkesin anlaması zımnında meclis-i mezkûrun teşkili...” bkz. İ.MSM, 25/653; MVL.d, 470/10. 11 Safer 1261/19 Şubat 1845. Meclis-i Maârif-i Muvakkat'ın Kuruluşu da burada zikredilmektedir.

19 Başkan ve üç üye ilmiye sınıfından, bir üye seyfiden ve iki üye de kalemiyeden oluşmaktadır. Üyelerin isimlerinin sunulduğu belge için bkz. İ.MSM, 3/46. 21 Safer 1261/17 Şubat 1845. Meclis-i Maârif-i Muvakkat'ın kuruluş iradesi 24 Safer 1261/4 Mart 1845 tarihinde çıkmıştır. Bkz. İ.DH, 99/4972. Ayrıca Takvim-i Vekâyi'de meclisin kuruluşu ve üyelerinin isimleri ilan edilmiştir. Bkz. Takvim-i Vekâyi, 4 Rebiülevvel 1261/13 Mart 1845, say1 283: 1, sütun 1-2; Mahmud Cevad İbnü'ş-Şeyh Nâfi, Maârif-i Umûmiye Nezâreti Tarihçe-i Teşkilat ve İcraatı (Matbaa-i Amire, 1338), 27-30. Meclisin kuruluşu ve faaliyetleri için bkz. Ali Akyıldız, Tanzimat Dönemi Osmanlı Merkez Teşkilâtında Reform (İstanbul: Eren Yayıncılık, 1993), 228-231. 
Görüşülmesi için Meclis-i Muvakkat'a ödev verilen maddelerden özellikle iki tanesinin, Dârulfünûn'un kuruluş yolunu açan nitelikte olduğunu söylemek mümkündür. Bu maddelerden birisi devlette istihdam olunacak görevlilerin yetişmesi için gereken ulûm ve fünûnun tespit edilmesi ve bunların öğretileceği bir nizamın yapılması ile alakalıdır. Burada 1839'da açılan Mekteb-i Maârif-i Adliye için daha önce bir takım nizamın yapıldığı lakin bunun uygulanamadığına işaret edilmektedir. Maddede belirtilen husus ile daha sonra yayımlanacak olan Dârulfünûn'un tesisinden bahseden belgede de devlete nitelikli eleman yetiştirilme hususu benzer şekilde ön plana çıkarılmaktadır. Söz konusu belgede Dârulfünûn hakkında şu ifade kullanılmaktadır: “...bundan asıl murâd-1 hakiki hidemât-1 mühimme-i saltanat-1 seniyyede kullanılmak üzere terbiye ve malumatlı bende-gân yetişdirilmek sureti olduğundan..."21

Meclis-i Muvakkat'a ödev verilen maddelerden bir diğeri ise reâyânın yani gayrimüslim tebaanın çocuklarının eğitimi için gerekenlerle ilgilidir. Reâyâ eğitim kurumlarının istenilen seviyede olmaması sebebiyle gayrimüslimlerin çocuklarını Avrupa'ya gönderdikleri ifade edilmektedir. Çocukların orada zararlı şeyleri öğrenmeleri sebebiyle ortaya devlet aleyhine sorun çıktığ 1 tespiti yapılarak bu sorunun da hal çaresine bakılması istenmektedir. Meclis-i Maârif-i Muvakkat'ın mazbatalarında bu madde çerçevesinde yeni bir "fünûn mektebi” açılmasının gündeme getirildiği ve aşağıda değinileceği üzere fünûn mektebine ilişkin önerilerle Dârulfünûn'un tesisine kapı aralandığı görülmektedir.

Belirlenen konuların müzakeresinde Meclis-i Maârif-i Muvakkat, dikkatini özellikle reâyâyı ilgilendiren maddeye yoğunlaştırmıştır. İlk sunulan mazbatalarda bu durum açık bir şekilde görülmektedir. ${ }^{22}$ Meclisin hazırladığı mazbatalarda gayrimüslim tebaanın çocuklarının eğitiminde sorun olarak ifade edilen meseleye ilişkin, reâyâya mahsus "fünûn mektebi" açılması yönünde bir çözüm önerisi sunulmaktadır. ${ }^{23}$ Buna gerekçe olarak reâyânın, lisan ve ulûm-1 riyaziye öğrenmek için Avrupa'ya veya Beyoğlu'ndaki Efrenc eğitim kurumlarına gitmesiyle oralarda devletin aleyhine siyasi ve politik zararlı fikirler öğrenmesinin önüne geçilmesi gösterilmektedir. Açılması önerilen bu kurumun "âdet-i mezhebiyye-i Nasârâ" etkisinden uzak olmasının yanında Saltanat-1 Seniyye'den görevlendirilmiş bir

21 İ. DH, 129/6634 lef 1. 22 Safer 1262/19 Şubat 1846.

22 İ.MSM, 25/654 lef 2 Meclis-i Maârif-i Muvakkat Mazbatas1. 19 Cemaziyelevvel 1261/26 May1s 1845.

23 Konu üzerinde görüş öne süren Türk tarihçilerin “fünûn mektebi”ne değinmedikleri görülmektedir. Bu mektebe ilişkin bilgiye yabancı araştırmacılardan Kiyohiko Hasebe çalışmasında yer vermiştir. $\mathrm{O}$, çalışmasında fünûn mektebi ile Dârulfünûn arasındaki ilişkiyi konu edinmiştir. Bkz. Kiyohiko Hasebe, "An Ottoman Attempt for the Control of Christian Education: Plan of Fünûn Mektebi (School of Sciences) in the Early Tanzimat Period", Osmanlı Araştırmaları/The Journal of Ottoman Studies, XLI (2013), 231-251. 
müdür tayini ile idâre ve nezâret ettirilmesi görüşü ileri sürülerek bu minval üzere bir karara varılması tavsiye edilmektedir.

Meclis, o günün şartlarında gayrimüslim tebaa için önemli bir yenilik olan "fünûn mektebi" açılmasıyla ilgili çözüm önerisine dair bir de uyarıda bulunmaktadır. Devlet tarafından reâyâya mahsus bir kurum açılmasının "ehl-i zimmeti i'zâz etmek" şeklinde anlaşıldığı; i'zâzın ${ }^{24}$ ise câiz olmadığı belirtilerek bu noktada ortaya çıan iki mahzurdan bahsedilmektedir. Birinci mahzur reâyânın eğitim için Avrupa'ya gitmesi ve orada devletin aleyhine "bir takım uygunsuz şeyler" tahsil etmesidir. İkincisi ise reâyâ için açılacak fünûn mektebinin "ehl-i zimmeti i'zâz etmek" manasına gelmesidir. Bu sebeple usûl-i fikha müracaatla bu iki mahzurun içtimaının gerekeceği ifade edilmekte ve iki durumdan hangisi ehven ise diğerine tercihte bulunulması istenmektedir.

Gündeme getirilen "fünûn mektebi” açma önerisi, önce Meclis-i Vâlâ'da akabinde de Meclis-i Umûmiye'de yapılan müzâkere neticesinde "ehven" olarak kabul edilmiştir. Reâyâya mahsus böyle bir kurumun açılışına onay verme gerekçeleri de sıralanmıştır. XIX. yüzyılda ticaret ve diğer işlerin önceki devirlere nispetle bir hayli genişlediği; sanayi ve sanatların giderek "fünûn" hükmüne girdiği; bu işlerle uğraşmak için bir takım yeni fikir ve fenlerin tahsil edilmesi gerektiği ifade edilmektedir. Müslüman tebaanın bu konularda eğitim imkânı bulduğu halde reâyânın söz konusu alanları tahsilden mahrum kalmaması için yeni kurumun açılmasına müsaade edilmesi gerektiği bildirilmektedir. Bu çerçevede fünûn mektebinin açılmasına ilişkin karar çıkmış; ayrıntıların ve düzenlemelerin Meclis-i Maârif-i Muvakkat'te "terbiyet-i âmme" kapsamında değerlendirilerek müzakere edilmesi istenmiştir. ${ }^{25}$

Meclis-i Maârif-i Muvakkat'ın ilk mazbatalarında önerilen “fünûn mektebi” açılma gerekçesinde belirtildiği üzere bu kurum sadece gayrimüslim tebaa için düşünülmüş ve anlaşıldığı kadarıyla kurumun yüksek seviyeli eğitim vermesi öngörülmüş̧ür. Müslümanların bu alana ilişkin gidebileceği mühendishane, tıp ve askerî eğitim kurumlarının varlığına işaret edilmektedir. Mazbatada belirtildiğine göre "fünûn mektebi" terkibindeki "fünûn"dan kastın "riyazî ilimler, sanayi, sanatlar ve meslekler" gibi alanlardır. ${ }^{26}$ Dolayısıyla gayrimüslim tebaa için kurulması düşünülen "fünûn mektebi"nde burada belirtilen alanların öğretiminin yapılması beklenmektedir.

Meclis-i Muvakkat'ın ilk önerisinde yer alan "fünûn mektebi” terkibinin, açılmas1 düşünülen kurumun özel ismi olarak mı yoksa eğitim kurumunun faaliyet alanını belirten genel bir isimlendirme olarak mı kullanıldı̆̆ı meselesi üzerinde durulmalıdır.

24 İ'zâz: Aziz kılmak, hürmet etmek.

25 İ.MSM, 25/654 lef 3. Meclis-i Umûmî Mazbatas1 13 Cemaziyelahir 1261/19 Haziran 1845.

26 İ.MSM, 25/654 lef 1-2. Meclis-i Vâlâ ve Meclis-i Maârif-i Muvakkat Mazbatas119 Cemaziyelevvel 1261/26 May1s 1845. 
Kurum hakkındaki belgelere bakıldığında terkibin, bir eğitim kurumu ismini andıran özel isimden ziyade daha çok verilecek eğitimin faaliyet alanına işaret etmek için kullanıldığ 1 görülmektedir. Bu konuya ilişkin Meclis-i Maârif-i Muvakkat'ın ilk mazbatalarında gündeme gelen yüksek eğitim veren kurum açılmasına yönelik fikir, dar anlamda öncelikle mesleğe dönük eleman yetiştiren ve gayrimüslim tebaaya mahsus bir fünûn mektebi açılması şeklindedir.

\section{Fünûn Mektebi’nden Dârulfünûn'a Geçiş}

Gayrimüslim tebaa için düşünülen "fünûn mektebi”nin açılmasına ilişkin hem Meclis-i Umûmî kararı olmasına hem de padişahın onay $1^{27}$ alınmasına rağmen bu kurumun akıbeti şu an için muğlak kalmıştır. Açılış onayı alındıktan sonra söz konusu kurumla ilgili çalışmalarda, bu işi "terbiyet-i umumiye" çerçevesinde değerlendirmek üzere Meclis-i Maârif-i Muvakkat vazifelendirilmiş olmakla birlikte meseleyle ilgili sonraki mazbatalarda kuruma ait bir hususa yer verilmemiştir.

“Fünûn mektebi”nin kuruluşuna ilişkin 16 Cemaziyelahir 1261/22 Haziran 1845 tarihli padişah iradesinden yaklaşık beş ay sonrasına ait bir belgede, Meclis-i Muvakkat'ın terbiyet-i umumiyeye dair tavsiyeleri görüşülmesine karşın, ne "fünûn mektebi” ne de gayrimüslim tebaanın eğitimine ilişkin bir mesele gündeme gelmiştir. Konuyla ilgili 6 Zilkade 1261/6 Kasım 1845 tarihli söz konusu bu belgede ${ }^{28}$ Meclis-i Muvakkat'ın ülke genelindeki terbiyet-i umumiyeyi Mekâtib-i Sıbyan, Mekâtib-i Rüşdiye ve Dârulfünûn şeklinde üç dereceye ayırdığı; bunlara ilişkin üç mazbata hazırlayarak üst meclise sunduğu ifade edilmektedir. Bu belge aynı zamanda şu an için ulaşılan "Dârulfünûn" isminin geçtiği ilk belgelerdendir. ${ }^{29}$

27 İ.MSM, 25/654 lef 3. Padişah İradesi 16 Cemaziyelahir 1261/22 Haziran 1845.

28 İ.DH, 113/5710. 6 Zilkade 1261/6 Kasım 1845.

29 Dârulfünûn isminin ilk ne zaman ortaya çıktığına dair İhsanoğlu, "Dârulfünûn kurulması ilk defa Meclis-i Muvakkat layihalarına dayanarak hazırlanan bu mazbatada [I. DH, 129/6634 no'lu belge kastediliyor.] zikredilmektedir. Yaptığımız arşiv belgeleri ve gazete taramalarında bu tarihten önce Dârulfünûn'a ait bir işarete rastlanmamıştır." demektedir ki sözünü ettiği belgenin tarihi 22 Safer 1262/19 Şubat 1846'tır. Bkz. İhsanoğlu, "Darülfünûn Tarihçesine Giriş: İlk İki Teşebbüs", 703, 7. Dipnot. Bu iddia şurada da tekrarlanmaktadır: İhsanoğlu, Dârülfünûn: Osmanlı'da Kültürel Modernleşmenin Odağl, I: 86. Ancak İhsanoğlu'nun belirttiği tarihten önce Dârulfünûn ismine rastlanmaktadır. Konuyla ilgili Hasebe de "Dârulfünûn" isminin ilk defa İ.MSM, 25/656 lef 1. 12 Zilkade 1261/12 Kasım 1845 tarihli belgede geçtiğini bildirmektedir. Bkz. Hasebe, "An Ottoman Attempt for the Control of Christian Education: Plan of Fünûn Mektebi (School of Sciences) in the Early Tanzimat Period", 246. Bununla birlikte bu tarihten altı gün öncesine tekabül eden İ.DH, 113/5710 nolu ve 6 Zilkade 1261/6 Kasım 1845 (Bu tarih belgenin arka sayfasında kayıtlıdır. Raporların sonunda bir tarih bulunmamaktadır.) tarihli belgede de "Dârulfünûn" ismi geçmektedir. Bütün bu bilgilerden sonra bir tarihe daha işaret etmek gerekmektedir. Burada künyesi verilen belgelere konu olan Meclis-i Maârif-i Muvakkat'ın sıbyan, rüşdiye ve Dârulfünûn hakkında hazırladığı üç kıta mazbata vardır. Bu mazbatalar yukarıda geçen 6 Zilkade 1261/6 Kasım 1845 tarihinden önce hazırlanmıştır. Dolayısıyla Dârulfünûn ismi bu tarihten öncesinde kullanılmaya başlamıştır, diyebiliriz. 
Dârulfünûn bu belgelerde, "tebaa-i saltanat-1 seniyyelerinin tahsil-i ulûm ve fünûn ile terbiye-i umumiye kaziyye-i hayriyesi" çerçevesinde değerlendirilerek hem Osmanlı tebaasının tümüne hitap etmekte hem de genel eğitimin yüksek basamağını oluşturması düşünülmektedir. Böylelikle Osmanlı Devleti'nde yeni bir yüksek eğitim verecek kurumun da tarih sahnesine çıktığına şahit olunmaktadır.

Burada dikkat çeken bir nokta "fünûn mektebi" hakkında irade çıkmasına rağmen bu konudan hiç söz edilmeden "Dârulfünûn" isminde yeni bir yapılanmanın gündeme gelmesidir. Bu noktada gayrimüslim tebaa için açılması kararlaştırılan "fünûn mektebi" yerine din ve mezhep ayrımı olmaksızın "tebaa-i saltanat-1 seniyyeleri" denilerek Osmanlı tebaasının tamamı için "Dârulfünûn" açma fikrine nasıl geçiş yapıldı̆̆ önem arz etmektedir. "Fünûn mektebi" terkibinin geçtiği belgede kurum, öncelikli olarak gayrimüslim tebaa için düşünülürken "mekâtib-i İslâmiyye” terkibiyle Müslümanlara mahsus olan eğitim kurumu vâkıasından ayrıca bahsedilmektedir. Ancak daha sonra çıkan 6 Zilkade 1261/6 Kasım 1845 tarihli lâhiyada, gayrimüslim tebaadan hiç bahsedilmeden kurulacak olan yeni kurumun, doğrudan "tebaa-i saltanat-1 seniyyeleri" tabiri kullanılarak öncekine nazaran hedef kitlesi genişletilmiştir. Buradaki ifade ile açılması kararlaştırılan böylesi bir eğitim kurumunun sadece gayrimüslim tebaa için değil tüm Osmanlı tebaası için olduğu resmen ilan edilmiştir. Bir anlamda gayrimüslim tebaaya mahsus eğitim kurumu tasavvurundan bütün Osmanlı tebaasının hizmetine sunulacak yüksek seviyeli bir eğitim kurumu tasavvuruna geçildiği görülmektedir. Ayrıca Meclis-i Vâlâ'nın eğitime ilişkin görüşülmesini istediği konulardan birisi ilk bölümde zikredilen devlette istihdam olunacak görevlilerin yetişmesi için gereken ulûm ve fünûnun tespit edilmesi ve bunların öğretileceği bir nizamın yapılması ile alakalı konu da Dârulfünûn fikrine geçişte etki etmiştir.

Öncelikli olarak belirtmek gerekir ki “fünûn mektebi"nden Dârufünûn'a geçişte en önemli dikkat çeken husus her ikisinin de "terbiyet-i umumiye" kapsamında değerlendirilmesidir. ${ }^{30}$ Burada “fünûn mektebi”nden Dârulfünûn'a geçiş meselesinde ne değişti de ilk başta sadece gayrimüslim tebaa için bir "fünûn mektebi”nin açılması düşünülüyorken bütün tebaayı kapsayacak şekilde bahsi geçen kurumun hitap ettiği kesim genişletildi?

Buna verilebilecek muhtemel cevaplardan birisi Meclis-i Muvakkat'ın ilk belgelerinde geçen ve birinci bölümde bahsedilen "gayrimüslimleri i'zâz" endişesini ortadan kaldırmak olabilir. Yani gayrimüslimlere mahsus bir eğitim kurumu yerine

30 Her iki oluşumu ilgilendiren belgelerde "terbiyet-i umumiye" görülmektedir. Örneğin bkz. İ.MSM, 25/654 lef 3. 16 Cemaziyelahir 1261/22 Haziran 1845; İ.DH, 113/5710. 6 Zilkade 1261/6 Kasim 1845. 
kapılarını herkese açan bir eğitim kurumu tesis etmek düşünülmüştür. İkinci olarak o dönemdeki fünûn kapsamında faaliyet gösterdiği söylenen Müslüman eğitim kurumlarının askerî nitelik taşıması hasebiyle sivillerin de gidebileceği ayrı bir kurum açma düşüncesine binaen "fünûn mektebi"nin kapsamı genişletilerek Dârulfünûn şekline dönüştürülmüş olabilir. Üçüncü olarak Osmanlı Devleti’nin sınırları içinde yaşayan farklı milletlerin hepsine aynı hizmeti götürme anlayışının benimsendiği Tanzimat fikrinin gereği olarak tebaayı birbirinden ayırmak yerine hepsini bir arada düşünmek lüzumundan kaynaklanabilir.

Devletin farklı milletlerdeki bütün fertlerini bir çatı altında birleştirmesi ve ilimlerin hepsinin bir arada okutulması için tesisi düşünülen kuruma "fünûn mektebi" yerine sonradan "dârulfünûn" terkibinin kullanılması daha kapsayıcı görülmüş olmalıdır. "Fünûn mektebi" terkibinin geçtiği belgede "fünûn"dan kasıt birinci bölümde değinildiği üzere dar anlamda sanat, hesap, riyaziyat gibi alanlardır. ${ }^{31}$ Buradaki "fünûn" kelimesinin, ilk başlarda söz konusu alanların eğitiminin yapılacağı bir kurumu kastetmek üzere kullanıldığını bize ihsas ettiriyor. Ancak "Dârulfünûn" isminin geçtiği belgelerde sadece sanat, hesap, riyaziyat gibi alanların değil bütün ulûm ve fünûnu kapsayacak geniş bir alanın eğitiminin yapılacağı bir kuruma işaret edilmektedir. Dolayısıyla Dârulfünûn'un kurulma aşamasında "fünûn" kelimesinin artık belli bir ilim grubunu değil, bilakis bütün ilimleri kastedecek şekilde kullanıldığı görülmektedir. Bu durum Dârulfünûn'un kuruluşuna ilişkin bilginin resmî olarak paylaşıldığı Takvim-i Vekâyi’de şöyle ifade edilmektedir: “...ve birisi dahi derece-i sâlisede olarak sunuf-1 teba-i saltanat-1 seniyyeden her kim olur ise olsun ikmal-i kemâlât-1 insaniyye etmek için kâffe-i ulûm ve fünûnu taallüm ve... anda hiçbir nev-i fen ve ilmin talim ve teallümü geri kalmamak... ve'l-hâsıl bilcümle levâzımât ve müteferriâtı kâmilen tesviye kılınmak üzere Dersaadet’te münasib bir mahalde Dârulfünûn inşası..."32

Görüldüğü gibi gayrimüslim tebaa için açılması düşünülen “fünûn mektebi” vücûd imkânı bulamamış ve bir anlamda tüm Osmanlı tebaasına hitap eden Dârulfünûn'a dönüşmüştür. Bu ikisi arasındaki ilişkiye işaret eden Hasebe, Dârulfünûn ile “fünûn mektebi”ni aynı meclisin düşündüğünü söylemesine rağmen bunları iki ayrı eğitim kurumu olarak değerlendirmektedir. ${ }^{33}$ Hasabe, "fünûn mektebi” ile ilgili belgeleri görmesine ve kurum hakkındaki fikirlerini bunlara dayandırmasına

31 Belgede şu şekilde geçmektedir: “...ve bunun sebeb-i zâhirisi ulûm-1 riyaziye ve fünûn-1 sâire tahsili...” Bkz. İ.MSM, 25/654 lef 2 Meclis-i Maârif-i Muvakkat Mazbatası.19 Cemaziyelevvel 1261/26 May1s 1845.

32 Takvim-i Vekâyi, 27 Receb 1262/21 Temmuz 1846, say1 303: 2, sütun 1.

33 Hasebe, "An Ottoman Attempt for the Control of Christian Education: Plan of Fünûn Mektebi (School of Sciences) in the Early Tanzimat Period", 243. 
karşın Dârulfünûn'a ilişkin bilgileri daha çok İhsanoğlu'nu kaynak göstererek vermektedir. ${ }^{34} \mathrm{Bu}$ sebeple arada bir bağlantı olduğunu ima etmekte fakat yeterli bir şekilde tartışmadan bunları iki ayrı eğitim kurumu olarak değerlendirip mukayesede bulunmaktadır. Ancak yukardaki tespitlerimize göre bunlar, müstakil iki kurumdan ziyade önce açılması düşünülen eğitim kurumunun sonradan hedef kitlesi genişletilmiş; okutulacak ulûm ve fünûnun da artırılmış şekli gibi görünmektedir. Yani ilk başta dar kapsamlı düşünülen "fünûn mektebi", daha sonra hem hedef kitlesi hem de içeriği genişletilerek Dârulfünûn’a dönüştürülmüştür, diyebiliriz.

\section{Dârulfünûn Terkibinin Tahlili}

Yeni bir yüksek eğitim verecek kurumun açılmasında "fünûn mektebi”" şeklindeki terkibin yerine "Dârulfünûn" terkibinin seçilmesi sıradan bir tercih olmasa gerektir. Bunun anlaşılması için Osmanlı Devleti'nde XIX. yüzyılda tüm tebaaya hitap edecek ve içeriği, "bütün ulûm ve fünûn"u kapsayacak şekilde geniş tutularak açllan yeni yüksek eğitim kurumunun isimlendirilmesinde tercih edilen "Dârulfünûn" terkibinin kendisi ve bu terkibi oluşturan "dâr" ve "fen" kelimeleri yakından incelenmelidir. Hem buradaki kelimeler hem de bu kelimelerle üretilen (oluşturulan) farklı terkipler kadim ilim, kültür ve eğitim tarihimizin ilk dönemlerinden itibaren XX. yüzyıla kadar işlevsel olarak kullanılagelmektedir. Aşağıdaki bölümde terkibi oluşturulan kelimeler incelenmektedir.

\section{"Dâr" Kelimesi}

İslâm tarihinin başlangıcından itibaren ilim, kültür ve eğitim müesseselerinin isimlendirilmesi kahir ekseriyetle, kurumlara verilen kavramların mekânla ilişkilendirilmesi şeklinde yapılmıştır. Bu ilişki genellikle ya "ev" kelimesi ile izafe kurularak ya da Arapçada ism-i mekân kalıbında gelen "medrese" ve "mekteb" kelimelerindeki gibi bu işin yapıldığı mekân kastedilerek yapılmaktadır. "Ev" kelimesi ile yapılan izafede "beyt, hâne ve dâr" kelimelerinden birisi kullanılmaktadır. "Beyt" kelimesi ile yapılan izafeye örnek olarak "Beytülhikme" verilebilir ki burası İslâm tarihinin ilk yüzyıllarında farklı ilim dallarında tercümelerin ve ilmî araştırmaların yapıldığı yüksek seviyeli bir oluşum kabul edilmektedir. "Hâne" kelimesiyle yapılan izafeye örnek olarak kütüphâne ve muallimhâne gibi terkipler verilebilir.

Bunlar arasında "Dârulfünûn" terkibinde de yer alan "dâr" kelimesi, kadim tarihimizde ilim, kültür ve eğitim müesseselerini ifade etmek için en yaygın

34 Hasebe, "An Ottoman Attempt for the Control of Christian Education: Plan of Fünûn Mektebi (School of Sciences) in the Early Tanzimat Period", 243-245.

35 Mahmud Kaya, “Beytülhikme”, DIA (İstanbul, 1992), VI: 88-90. 
kullanılan anahtar kavramlardan birisidir. "Dâr" kelimesinin sözlük manası evdir. Lakin bu sözlük manası ilim, kültür ve eğitim meseleleri söz konusu olduğunda, bu konularla ilgili mekânı veya kurumu ifade eden terim anlamı kazanmıştır. İslâm tarihinde bu kelimenin ilk defa, Hz. Peygamber'in (sav) tebliğinin birinci dönemi olan Mekke'de kullanıldığı görülmektedir. Kur'ân-1 Kerim'in ilk inen ayetlerinin ve İslâm dininin esaslarının anlatıldığı Erkam bin Ebi'l-Erkam elMahzûmî'nin evi “Dâru'l-erkam" (Erkam'1n evi) olarak bilinmektedir. ${ }^{36}$ Dâru'lerkâm, Hz. Peygamber'in (sav) seçkin sahabesinin eğitim gördüğü bir mekân hüviyetindedir. Terkipte kullanılan "dâr" kelimesi, sonraki dönemlerde de eğitim öğretim faaliyetlerinin yürütüldüğü yerler için işlevsel bir anahtar kavram olarak kullanılmıştır. Kelimenin buradaki işlevi kadim ilim, kültür ve eğitim tarihimizde, bahsi geçen alanların mekânsal ve kurumsal yönüne işaret etmektedir.

Anahtar kavram olarak ifade ettiğimiz "dâr" kelimesi ile kadim ilim, kültür ve eğitim tarihimizde birçok kurumun olduğu görülmektedir. Bunlardan bazıları şunlardır: Dârülkurrâ3 ${ }^{37}$, Dârülkütüb (h. I./m. VII. yy) $)^{38}$, Dârülilim (h. IV./m. X. yy) ${ }^{39}$, Dârülhikme (1004) ${ }^{40}$, Dârülhadis (h. 566/m. 1170) ${ }^{41}$, Dârülulûm (1693) $)^{42}$, Dârüttıbâa $(1727)^{43}$, Dârüttıbb-1 Âmire [Mekteb-i Tibbiyye] $(1827)^{44}$, Dârulmuallimîn $(1848)^{45}$, Dârülmaârif (1850) ${ }^{46}$, Dârü'l-Hilâfeti'l-Aliyye Medresesi (1914) ${ }^{47}$, Dârü'l-Hikmeti'lİslâmiyye (1918-1922) ${ }^{48}$.

Örneklerden anlaşıldığı kadarıly İslâmiyetin ilk yıllarından itibaren "dâr" kelimesinin ilim, kültür ve eğitim müesseselerini ifade etmek üzere XX. yüzyıla kadar kullanıldığı görülmektedir.

36 Asım Köksal, “Dârülerkam”, DİA (İstanbul, 1993), VIII: 520-521.

37 Nebi Bozkurt, "Dârulkurrâ", Dİ (İstanbul, 1993), VIII: 543-545. Hz. Peygamber'in Medine döneminde Mahreme b. Nevfel'in evine "dârulkurrâ" ismi verildiği bildirilmektedir. Daha sonra bu isim Kur'ân-1 Kerim'in okuyuş tarzlarıyla birlikte hafızlık eğitiminin de verildiği mekânların ismi olmuştur.

38 İsmail E. Erünsal, "Dârülkütüb”, DİA (İstanbul, 2003), XXVII: 11-32.

39 İsmail E. Erünsal, "Dârülilim”, DİA (İstanbul, 1993), VIII: 539-541.

40 Mahmut Kaya, "Dârülhikme”, DİA (İstanbul, 1993), VIII: 537-538.

41 Nebi Bozkurt, "Dârülhadis", DIA (İstanbul, 1993), VIII: 527-529.

42 Azmi Özcan, “ Dârülulûm”, DİA (İstanbul, 1993), VIII: 553-555.

43 Turgut Kut, "Dâruttıbâa", DİA (İstanbul, 1994), IX: 10-11.

44 Nil Sarı, "Mekteb-i Tibbiyye", DİA (İstanbul, 2004), XXIX: 2-5.

45 Cemil Öztürk, "Dârülmuallimîn", DİA (İstanbul, 1993), VIII: 551-552.

46 M. Hüdai Şentürk, "Dârülmaârif”, DİA (İstanbul, 1993), VIII: 548-549.

47 Mübahat S. Kütükoğlu, "Dârü'l-Hilâfeti'l-Aliyye Medresesi”, DİA (İstanbul, 1993), VIII: 507-508.

48 Sadık Albayrak, "Dârü'l-Hikmeti'l-İslâmiyye”, DİA (İstanbul, 1993), VIII: 506-507. 


\section{"Fünûn" Kelimesi}

Dârulfünûn terkibinin diğer unsuru "fünûn"un tekili olan "fen” kelimesi, kadim ilim geleneğimizin oluşmaya başladığı dönemlerde herhangi bir ilmî disiplini, ya da bir ilme ait alt disiplinlerin her birini karşılayacak şekilde kullanılmaktadır. ${ }^{49}$ Sözlükte "fen” kelimesi, nev', çeşit ve sürmek (bir hayvanı sürmek) manasına gelmektedir. Fen kelimesinin çoğulu "efnân”, bunun çoğulu da "efânîn” olup, sonuncusunun manası ağaç budakları anlamındadır. ${ }^{50}$ Kelimenin çoğulu "fünûn" şeklinde de gelmektedir. Bir adamı aldatmak manasına olup "fend" diye de isimlendirilmektedir. Kelime, tezyin etmek manasını da karşılamaktadır. ${ }^{51}$

"Fen” kelimesinin çoğulu olan "fünûn”, ilimler tasnifinin yapıldığı kitaplarda tek bir ilmi karşılamaktan ziyade edebî, lügavî, dinî, hikemî, riyazî, tabî̂ ve benzeri ilimlerin bütününü ifade etmekte kullanılmıştır. Bu ilimlerin hepsine birden ya da belli bir ilim grubuna "fünûn” denilmiştir. Örneğin XVI. yüzyılda Nev'î (ö.1599), ilimleri tanıttığı kitabının isimlendirilmesinde şunları söylemektedir: “. . .ve müddet-i talebümde her fenden cem' itdüğüm mesâil-i mühimmeyi -ki fehmi eshel ve nef'i eşmel ola- her mahalde derc itdüm. Ol sebebden kitaba 'Netâyicü'l-Fünûn' deyu ad virdüm..." Nev'̂̂, müstakil olarak ilimlerin her birine branş anlamında "fen" demiş ve ayırım yapmaksızın bütün ilimleri "fünûn” kavramıyla karşılamış; bunların arasında usûl-i dini “umdetü'l-fünûn” olarak vasıflandırmıştır. ${ }^{52}$ Buna benzer bir şekilde Nev'î ile muasır olan Sipâhîzâde Mehmed'in (ö.1589) Enmûzecü'l-Fünûn fi'l-Maârifi'l-âmme isimli eserinde de tefsir, hadis, kelâm, usûl-i fikıh, ferâiz, meânî, tıp ve astronomi gibi ilimlere yer verilmiştir. ${ }^{53}$ XVII. yüzyılda yaşayan Kâtib

49 İlhan Kutluer, "İlim”, DİA (İstanbul, 2000), XXII: 110.

50 Mehmed Efendi Vani Vankulu, Lugat-ı Vankulu: Tercüme-i Slhah-ı Cevheri (Kostantiniye: Dârü't-Tibâati'l-Cedîdeti'l-Ma'mûre, 1218/1803), II: 541.

51 Ebü't-Tahir Mecdüddin Muhammed b. Yakub b. Muhammed Firuzabadi, el-Okyanusü'l-Basit fi Tercümeti Kamusü'l-Muhit (Kamus Tercümesi), Tercüme: Mütercim Asım Efendi (İstanbul: Matbaa-i Osmaniye, 1305), 684. Ayrıca "fen" kelimesi, sıkıntı, zorluk, cefa manalarına da gelmektedir. Bkz. Ebü'l-Fazl Muhammed b. Mükerrem b. Ali el-Ensârî İbn Manzur, Lisanü 'lArab, Hazırlayan: Emin Muhammed Abdülvehhab-Muhammed es-Sadık el-Ubeydi (Beyrut: Dârü'l-ihyâi't-Türasi'l-Arabî, 1417/1997), 337.

52 Yahya Nev'î, Illimlerin Özü (Netâyicü'l-Fünûn), Hazırlayan: Ömer Tolgay (İstanbul: İnsan Yayınları, 1995), 73-74. Nev'î Efendi, kitabında tanıttı̆̆ı ilimleri şu şekilde sıralamaktadır: “Zikr-i tertîb-i fünûn: İlm-i tarih, ilm-i hikmet, ilm-i hey’et, ilm-i kelâm, ilm-i usûl, ilm-i hilâf, ilm-i tefsir, ilm-i tasavvuf, ilm-i ta'bir-i ru'ya, ilm-i ruky ve efsun ve tıbb, ilm-i felâhat, ilm-i nücûm, ilm-i fâl-u zecr." Yazar, tanıttığı ilimlerin bu şekilde sıralanışı hakkında da şöyle demektedir: “...Sebeb budur ki ilm-i tarihi ilm-i hikmet ve hey’et takib itmişdir. Ba'de zâlike umdetü'l-fünûn ilm-i usûl-i din zikrolunmuşdur. Sâiri dahî sümme ve sümme ale’t-tertîb birbirini takib itmişlerdir. Emmâ cümleden maksûd ma'rifet-i zât-1 Ma’bûd'dur.” Bkz. a.e., s. 75-76.

53 Bkz. Mahmut Kaya, "Sipâhîzâde Mehmed”, DİA (İstanbul: 2009), XXXVII: 258-259. 
Çelebi'nin (ö.1657) Keşfü'z-Zünûn an Esâmi'l-Kütüb ve'l-Fünûn adlı eserinde de çeşitli alanlardaki ilimlerin tamamı "fünûn" kelimesiyle karşılanmıştır. ${ }^{54}$

Aynı şekilde XVIII. yüzyıl âlimlerinden Tehânevî’nin (ö.1745'ten sonra), Keşşâfü’lIstılâhâti'l-Fünûn isimli kitabı da örnek verilebilir. Kitabın mukaddimesinde ulûm ve fünûnu bilmek için ıstılahlara ihtiyaç olduğu ifade edilmektedir. Bunları açıklamak üzere farklı alanlarda 1stılah lügatleri oluşturulmuştur. Tehânevî, insanlar arasında geçerli bulunan bütün ilimlere ait ıstılahları içeren bir kitabın olmadığını ifade ederek eserine "Keş̧̧̂fü Istılâhâti'l-Fünûn" ismini vermiştir. Tehânevî burada herhangi bir ayırım yapmadan tıpkı Nev'î, Sipâhîzâde ve Kâtib Çelebi gibi, ilimlerin hepsini birden "fünûn" kelimesiyle karşılamıştır. ${ }^{55}$ Kitapta ilm-i sarf'tan ilm-i fikh'a, ilm-i hikmet'ten ilm-i nücûm'a kadar ellinin üstünde sayılan ilimlere ait 1stılahlar açıklanmıştır. ${ }^{56}$ Bunların yanında 1740 'lı yıllarda kaleme alınan Kevâkib-i Seb'a isimli eserde de medrese talebesinin tahsil hayatı boyunca üstaddan alacağı farklı alanlardaki ilimleri göstermek için "tertîb-i fünûn" tabiri kullanılmıştır. ${ }^{57}$ Tertîb-i fünûn terkibinin buradaki anlamı, medrese eğitim anlayışında okunacak ilimlere ait müfredat programını karşılamaktadır.

"Fünûn" kelimesi, ilimlerin hepsini ya da tek bir ilmin alt kısımlarını ifade etmek üzere çeşitli kitap adlarının oluşturulmasında da kullanılmıştır. Örneğin hicrî IV. yüzyılın başında vefat eden Ebû Ca'fer Muhammed b. Süleyman Kûfí (ö. 309/921) Kitâbü'l-Müntehab ve yelîhi Kitâbü'l-Fünûn ismini verdiği eserin ikinci bölümü olan Kitâbü'l-Fünûn'un konusu İslâm fikhıdır. Kitabın “fünûn” kelimesi ile isimlendirilen bölümünde fikıh ilminin nikâh, alış veriş, vasiyet ve rehin gibi alt konuları vardır..$^{58}$

54 Hacı Halife Mustafa b. Abdullah Katib Çelebi, Keşfü'z-Zünûn an Esâmi'l-Kütüb ve'l-Fünûn, Tashih: M. Şerefettin Yaltkaya, Kilisli Rifat Bilge (Ankara: Milli Eğitim Bakanlığı, 1941).

55 Tehânevî’nin, tahsil hayatı boyunca, bütün ilimlere ait 1stılahları içeren bir kitap telifi gönlünü meşgul etmiştir. Ulûm-1 Arabiye ve Şer'iyye'yi babasından tahsil ettikten sonra ciddi bir şekilde ilimlerin hazinelerini elde etmeye girişmiştir. Başka hocalardan ilim tahsili mümkün olmadığını ifade etmektedir. Bundan dolayı zamanının yarısını ilimlerin muhtasarlarını mütâlaa ile geçirdiği esnada 1stılahları iktibas ederek tek tek yazmıştır. Bkz. Muhammed b. A'lâ b. Ali el-Faruki el-Hanefi Tehânevî, Keşşâfu Istılâhâti'l-Fünûn, Haşiye: Ahmed Hasan Besic (Beyrut: Dârü'l-Kütübi'l-İlmiyye, 1418/1998), I: 5.

56 Tehânevî, Keş̧̧âfu Istılâhâti 'l-Fünûn, 20-67. Bunun gibi Saçaklızâde (ö. 1145/1732) de, Seyyid Şerif'e (ö. 816/1413) nisbet edilen “Istılâhâtü'l-Fünûn” isimli bir eserden bahsetmektedir. Bkz. Şeyh Muhammed bin Ebî Bekr el-Mer'aşî eş-Şehîr bi Saçaklızâde, Tertîbü'l-Ulûm, Tahkik: Muhammed b. İsmail es-Seyyid Ahmed (Beyrut: Dârü'l-Beşâiri'l-İslâmiyye, 1988), 158.

57 XVIII. Asrın Ortalarına Kadar Türkiye'de İlim ve İlmiyeye Dâir Bir Eser: Kevâkib-i Seb'a Risalesi, Metni yeni harflere ve ekinde Fransızca metinleri Türkçeye Çeviren: Nasuhi Ünal Karaarslan (Ankara: Türk Tarih Kurumu, 2015), 71.

58 Ebû Ca'fer Muhammed b. Süleyman Kûfî,, Kitâbü'l-Müntehab ve yelîhi Kitâbü'l-Fünûn (San'a: Dârü'l-Hikmeti'l-Yemaniyye, 1993), 7. 
İbn Akîl'in de (ö. 513/1119) Kitâbü'l-Fünûn isimli bir eseri bulunmaktadır. Eserin muhakkiki George Makdisi (1920-2002), mukaddimede İbn Receb'den bu kitap için şunları nakletmektedir: "Kitâbü'l-Fünûn, İbn Akîl'in en büyük tasnifidir ve bu cidden büyük bir kitaptır. Onda vaaz, tefsir, fikıh, usûl, nahiv, lügat, tarih ve hikâyât hakkında çok büyük faydalar bulunmaktadır..."59 Fünûn kelimesinin yer aldığı diğer kitap isimlerine şunlar da örnek verilebilir: Fünûnü'l-Acâib, ${ }^{60}$ Tarihü’lKudâi: Kitâbü Uyûni'l-Maârif ve Fünûni Ahbâri'l-Halâif, ${ }^{61}$ Nihâyetü'l-Ereb fî Fünûni'l-Edeb, ${ }^{62}$ Kavâidü’t-Tahdis min Fünûni Mustalahi'1-Hadis. ${ }^{63}$

Bunların yanında fünûn kelimesinin XIX. yüzyıldaki metin ve belgelerde nasıl geçtiğine bakıldığında birkaç farklı anlama gelecek şekilde kullanıldığı müşahede edilmektedir. İlk olarak fünûn kelimesinin belli bir alandaki bilimler ya da dersler manasını içerecek şekilde kullanımı bulunmaktadır. Örneğin 1275/1859'da Mekteb-i Mülkiye'de okutulacak dersler için fünûn kelimesi tercih edilmiştir: “...tanzim olunarak okunacak fünûn için lüzumu olan hocalar..." ${ }^{״ 4}$ Buradaki fünûn kelimesi

59 Ebü'l-Vefa Ali b. Akîl b. Muhammed el-Bağdadi İbn Akîl, Kitâbü'l-Fünûn, Tahkik: George Makdisi (Beyrut: Dârü'l-Maşrık, 1970), 17. Ayrıca bu kitaptan seçmeler yapılarak bir kitap oluşturulmuştur. Kitabın ismi ve künyesi şu şekildedir: Ebü'l-Vefa Ali b. Akîl b. Muhammed el-Bağdadi İbn Akîl, Zehrü'l-Ğusûn min Kitâbi'l-Fünûn, Tahkik: Kamil Muhammed Harrât (Dımaşk: Dârü't-Tevfik, 1420/1999). Tahkiki yapan kitaba “Kitâbi'l-Fünûn'dan Dalların En Parlağı” ismini vererek kitabın asıl ismine işaret etmek istediğini ifade etmektedir. Bkz. a.e., s. 7.

60 Ebû Saîd Muhammed Ali b. Amr b. Mehdi el-Hanbeli Nakkaş, Fünûnü'l-Acâib, Tahkik: Mustafa Abdülkadir Ata (Beyrut: Müessesetü'l-Kütübi's-Sekafiye, 1990). Bu kitapta Nakkaş, dinlediği hadisleri yazmıştır.

61 Ebu Abdullah Muhammed b. Selâme b. Ca'fer Kudâî, Tarihü'l-Kudâi: Kitâbü Uyûni'l-Maârif ve Fünûni Ahbâri'l-Halâif, Tahkik: Cemil Abdullah Muhammed el-Misrî (Mekke: Câmiatü Ümmi'l-Kurâ, 1415/1995). Kitap, yaratılışın başlangıcından Kudâî'nin kendi zamanına kadar gelişen tarihi olaylardan bahseden muhtasar bir tarih kitabıdır. Bkz. a.e., s. 32-37. Kitabın konusundan hareketle "fünûn" kelimesinin burada sözlükteki "çeşitler, türler" manasında kullanıldığı görülmektedir. Aynı şekilde "fünûn” kelimesinin sözlük manasındaki kullanımına örnek için bkz. Ebû Abdullah Muhyiddin Muhammed b. Ali İbnü'l-Arabî, Şücûnü'l-Mescûn ve Fünûnü'l-Meftûn, Tahkik: Ali İbrâhim Kürdi (Dımaşk: Dâru Sa'deddin, 1419/1999).

62 Şehabeddin Ahmed b. Abdülvehhab b. Muhammed Nüveyri, Nihâyetü'l-Ereb fí Fünûni'l-Edeb (Kâhire: Vizâretü's-Sekâfe ve'l-İrşâd, tarih yok). Bu kitaptaki "fünûn" kelimesi de bölüm başlıklarını ifade etmek üzere kullanılmıştır. Beş fenden oluşan kitabın birinci fenni gökyüzünün ve yeryüzünün yaratılışıyla, ikinci fenni insan ile ilgili, üçüncü fenni hayvanlarla, dördüncü fenni bitkilerle ve beşinci fenni de tarih ile ilgilidir.

63 Cemaleddin Muhammed b. Muhammed Saîd Cemaleddin Kâsımî, Kavâidü't-Tahdis min Fünûni Mustalahi'l-Hadis (Dımaşk: Matbaatu İbn Zeydun, tarih yok). Bu kitap hadis usûlünden bahsetmektedir. Yazar, mukaddimenin sonunda konuyla ilgili yazılmış bir kısım eserleri ve yazarları zikrettikten sonra şöyle demektedir: “...ve Allah Teâlâ'nın yardımıyla bu fennin maksatlarının özünü yazdım.” Bkz. a.e., s. 10-11.

64 Takvim-i Vekâyi, 18 Cemaziyelahir 1275/23 Ocak 1859, say1 567: 3, sütun 1. 
ile kastedilen ekonomi politik, tarih, hesab, coğrafya, nizamât-1 devlet-i aliyye, muâhedât-1 mevcûde, fenn-i kitâbet, ${ }^{65}$ hendese-i ameliye, istatistika, hukuk-1 milel gibi derslerdir. ${ }^{66}$

Medresede okutulan ilmler için de 1290/1873'te sunulan bir raporda fünûn kelimesinin kullanıldığı görülmektedir: “...binâen aleyh eslâf-1 kirâm talim ve taallüm-i fünûna kıyam ve mesâil-i mütûna itina ve ihtimam ile nâil-i merâm olmuşlar ise de..." ${ }^{67}$ F1kıh ağılıklı eğitim verilen 1291/1874'te Muallimhâne-i Nüvvâb hakkında hazırlanan talimatnamede öğrencilerin gördüğü dersleri ifade etmek için fünûn kelimesi kullanılmaktadır: “... bunlardan tederrüs etmiş oldukları fünûnun her birinden seçilen münasip üçer sual îrâd olunarak..." ${ }^{98}$ Benzer şekilde Dârulfünûn-1 Sultanî müdürü Sava Paşa da (1832-1904) Edebiyat Mektebi'nde okunacak dersler için fünûn kelimesini kullanmaktadır: "Edebiyat Mektebi'nde okutulmakta olan ulûm ve fünûn şunlardır: Edebiyat-1 Arabiye ve Yunaniye ve Latiniye, Hikmet, Mantık, Tarih-i Umûmi, İlm-i Esâtiri'l-evvelin, İlm-i âsâr-1 Atika." ${ }^{99}$

XIX. yüzyılda fünûn kelimesinin ikinci olarak aldığı başka bir anlamda, birbirinden farklı alanlardaki eğitim kurumlarını ifade etmek üzere kullanılmaktadır. Örneğin deniz mühendishanesi için Mekteb-i Fünûn-1 Bahriye ${ }^{70}$; tıp için Mekteb-i Fünûn-1 T1bbiye ${ }^{71}$; Mekteb-i Harbiye için Mekteb-i Fünûn-1 Harbiye, ${ }^{72}$ mülkiye için Mekteb-i Fünûn-1 Mülkiye ${ }^{73}$ şeklinde isimlendirmeler yapılmıştır. Ortaçağ Avrupa eğitim kurumlarını tanımlamak için de Mekteb-i Fünûn ismi kullanılmaktadır ki burada okutulan dersler sarf, nahiv, ilm-i beyan, hikmet, ilm-i hesab, hendese, müzik ile ilm-i heyet şeklinde sayılmaktadır. ${ }^{74}$ Said Paşa da (1838-1914) yabancı ülkelerdeki üniversitelerin bölümlerini şu şekilde tanımlamaktadır: “...Bunlar, Fünûn-1 T1bbiye,

65 İ.MMS. 12/519. 25 Ramazan 1274/9 May1s 1858.

66 Mücellitoğlu Ali Çankaya, Mülkiye Tarihi ve Mülkiyeliler 1859-1949. (Ankara: Örnek Matbaas1, 1954) 16-17.

67 Takvim-i Vekâyi, 15 Safer 1290/14 Nisan 1873, say1 1570: 1.

68 İST. MFT. MSH. DFT. 3/1999. Gurre-i Muharrem 1291/18 Şubat 1874.

69 Sava Paşa, "Mukaddime”, Mekâtib-i Âliye-i Fenniye yani Dârulfünûn-ı Sultanî'nin Nizamnâme-i Dâhiliyesiyle Dürûs Cedvelidir. (La Türki Matbaasında tab olunmuştur, 1293) 9.

70 İ.MSM, 29/807 lef 2. 1 Rabiyyülevvel 1259/1 Nisan 1843.

71 İ.MSM, 25/669. 6 Rabiyyülevvel 1263/22 Şubat 1847.

72 C.AS, 839/35813 lef 112 Rabiyyülâhir 1251/7 Ağustos 1835; İ.MSM, 13/276 lef 410 Ramazan 1262/1 Eylül 1846.

73 HR.TH. 33/13. 13 Şevval 1296/30 Eylül 1879; MF.MKT. 65/37. 25 Receb 1297/3 Temmuz 1880.

74 Sava Paşa, "Mukaddime”, Mekâtib-i Âliye-i Fenniye yani Dârulfünûn-ı Sultanî’nin Nizamnâme-i Dâhiliyesiyle Dürûs Cedvelidir. (La Türki Matbaasında tab olunmuştur, 1293) 5. 
Ulûm-1 Hukukiye, Fünûn-1 Hikemiye ve Edebiye, Fünûn-1 Riyaziye ve İlâhiyat Dârulicâzeleridir." ${ }^{\text {75 }} \mathrm{Bu}$ örneklerde fünûn kelimesi; riyazi, hikemî, edebî, tıp, hendese ve benzeri ilimlerde kullanılmıştır.

Fünûn kelimesi üçüncü olarak “...ve sanayi ve hiref ise gitgide incelerek fünûn hükmüne girmiş..." "76 örneğinde olduğu gibi sanayi, meslekler ve sanatlar manasında kullanılmaktadır.

Dördüncü olarak bir diğer kullanımında fünûn kelimesinin riyazi ve tabii bilimleri karşıladığı görülmektedir. 1847'de Takvim-i Vekâyi'de Almanya ve Fransa mektepleri hakkında yayımlanan bir haberde öğretmen yetiştiren okulların edebiyat ile fünûn ve ulûm-1 riyaziye kısmı şeklinde ikiye ayrıldığı bildirilmektedir. ${ }^{77}$ Bu şekildeki ayırım Mekteb-i Sultanî'de $(1868)^{78}$ ve Dârulmuallmîn'in Âliye Şubesi'nde de $(1848)^{79}$ bulunmaktadır. Fünûn şubesinde riyaziyat ve tabiiyyat dersleri yer almaktadır.

XIX. yüzyıldaki metinlere bakıldığında fünûn kelimesinin ulûm kelimesiyle "ulûm ve fünûn” şeklindeki kullanımının çok yaygın olduğu görülmektedir. Örneğin 1264/1847'de Avrupa'daki okullarla ilgili bir raporda: “...Almanların sair ulûm ve fünûn mekteplerinden başka fakir çocukların terbiyeleri için beş çeşit mekâtib-i mahsusa bulunmaktadır..." "80; 1266/1850'de Dârulmaârif' in açılmasıyla ilgi bilgide: “...Mekâtib-i Rüşdiye'ye mahsus ulûm ve fünûnun mâfevkinde olarak tahsil-i fenn-i kitâbete medâr olacak bazı fünûn ve maârif..." "; 1 1309/1892'de Mekteb-i Mülkiye-i Şahane (1859) hakkında çıkarılan kararnâmede muallimlerin tedris edecekleri fünûn ve ulûm derslerini, bunlar arasında da özellikle fikıh, akâid-i diniyye, ahlâk ve terbiyeye dair olan dersleri ayrıntılarıyla ve hakkıyla öğretmeye gayret göstermeleri istenmektedir. ${ }^{82}$ 1314/1896' da Dârulfünûn-1 Şahane (1900) nizamnamesi ile ilgili belgede: “...bir de umûr-1 siyasiye-i hâriciyede kullanılacaklara mahsus olmak ve bunlara muktezi ulûm ve fünûn talim olunmak üzere..." ${ }^{93}$ Verilen örneklerde "ulûm ve fünûn" ile eğitim kurumlarında okutulacak birbirinden farklı alanlardaki dersler kastedilmektedir.

75 Said Paşa'nın Hatıratı. (Dersaâdet: Sabah Matbaas, 1328), I: 572-573.

76 İ.MSM, 25/654 lef 1-2. 19 Cemaziyelevvel 1261/26 Mayıs 1845.

77 Takvim-i Vekâyi, 11 Muharrem 1264/19 Aralık 1847, sayı: 361.

78 Mekteb-i Sultani Tevzi-i Mükâfat Cedvelidir. (Kostantiniye: Matbaa-i Ebuzziyâ, 1301) 7.

79 Salnâme-i Nezaret-i Maârif-i Umûmiyye. (Matbaa-i Âmire, 1316), 1. Sene: 131.

80 Takvim-i Vekâyi, 20 Muharrem 1264/28 Aralık 1847, sayı: 362.

81 Takvim-i Vekâyi, 29 Şaban 1266/10 Temmuz 1850, sayı: 427, sayfa 2, sütun 2.

82 Salnâme-i Nezaret-i Maârif-i Umûmiyye. (Matbaa-i Âmire, 1316), 1. Sene: 67.

83 Y.A.RES. 81/60 lef 2. 10 Safer 1314/21 Temmuz 1896. 
Fünûn kelimesi ile ulûm kelimesinin birbirinin yerine kullanıldığ 1 örnekler de bulunmaktadır. Yukarıda zikredilen Mekteb-i Fünûn-1 Bahriye için 1253/1837 tarihli bir arşiv belgesinde Mekteb-i Ulûm-1 Bahriye ismi kullanılmaktadır. ${ }^{84}$ Bununla ilgili bir başka örnek de Mekteb-i Sultanî'nin 1316/1898'deki ders programında "fen şubesi” yerine "ulûm şubesi” tabirinin kullanıldı̆̆ı görülmektedir: “...Ulûm Şubesi dahi riyaziyat ve tabiiyyat derslerini hâvidir." ${ }^{85}$

Yukarıdaki örneklerde Dârulfünûn terkibindeki “fünûn” kelimesinin, kadim ilim, kültür ve eğitim tarihimizdeki anlam genişliğine paralel olarak XX. yüzyıla kadar sürekli gündemde kaldığı; çok farklı alanlardaki ilimleri, disiplinleri, sanatları, sanayii ve benzerlerini ifade etmek üzere kullanıldığı ve çeşitli dönemlerde hazırlanan ders programlarında değişik ilimleri karşıladığı görülmüştür. Bununla birlikte "fünûn" kelimesi, giriş kısmında nispeten değinildiği üzere bir kısım tarihçi tarafından, diğer manaları çok fazla dikkate alınmadan dar anlamda fizik, kimya, matematik gibi ilimleri çağrıştıracak şekilde anlaşılmıştır. ${ }^{86}$ Birçok ilmi kapsayan anlam genişliğine rağmen "fünûn" kelimesinin sadece tabiî ilimlere hasredilişi, "Dârulfünûn" isminin ilk kez ortaya çıkmasından çok sonralarına denk gelmektedir. Örneğin tabiî ilimler alanında 1279/1862'de Münif Efendi’nin (18301910) çıkardığı Mecmua-i Fünûn'un birinci sayısında "fünûn" kelimesine yönelik bir çerçeve çizilmiştir. Derginin "Mukaddime" kısmında mecmuanın nasıl çıkacağı ve nelerden bahsedeceği ile ilgili şöyle söylenmektedir: “...herkesin anlayacağı surette sehlü'l-ibâre olmak üzere diyanet ve zaman-1 hâl-i politikasından mâadâ kâffe-i fünûn ve sanayia müteallik malumât-1 nâfiayı müştemil olacaktır." ${ }^{{ }^{87}}$ Benzer şekilde yayımlanan başka dergilerde de bu bakış açısının varlı̆̆ devam etmektedir. Örneğin 1308/1890'da çıkan bir dergide fen şu şekilde tanımlanmaktadır. "Fen, tabiatın hazâin-i servetini insanın yed-i istifadesine tevdi ettiği cihetle ikbâl ve saâdet-i cismaniyesine dahi bâdî olur. Fen sayesinde insan kuvâ-yı tabiiyyeyi kendisine hâdim kilar. Kendisi de o sayede tabiata daha ziyade hizmet eder." ${ }^{\text {88 }}$ 1329/1911 yılında da Fen isimli bir gazete çıkmaktadır. Gazetenin başlık kısmında şunlar yer almaktadır: "Fünûn-1 riyaziye ve tabiiyeden ve bilcümle fünûn-1 mezkûraya mütallik tatbikat ve usûl-i tedrisiyeden bâhis her hafta Perşembe günleri neşr

84 C.MF, 1/31 lef 2. 24 Rabiyyülevvel 1253/28 Haziran 1837.

85 Mekteb-i Sultani Ders Programıdır. (İstanbul: Âlim Matbaas1, 1316) 3.

86 Örneğin bkz. Berkes, Türkiye'de Çağdaşlaşma, 232-235; İhsanoğlu, "Darülfünûn Tarihçesine Giriş: İlk İki Teşebbüs”, 699; İhsanoğlu, Dârülfünûn: Osmanlı'da Kültürel Modernleşmenin Odağl, 80; İsmail Doğan, “Osmanlı Bilimsel Topluluklarının Türkiye'deki Bilim Eğitimine Etkileri”, Ankara Üniversitesi Ĕ̆itim Bilimleri Fakültesi Dergisi (1993), XXVI/1: 135.

87 Münif Efendi: "Mukaddime”, Mecmua-i Fünûn (İstanbul, 1279), Numara 1: 19.

88 Fünûn, Âsar-1 Müteaddide-i Cedideden Mütercem, Mütercimi: M. Ali, Birinci Cüz, İstanbul, Şirket-i Mertebiye Matbaası, 1308, d. 
olunur fennî gazetedir." ${ }^{" 89} \mathrm{Bu}$ örnekleri çoğaltmak mümkündür. Bunlara ilave olarak Dârulfünûn'un 1279/1863'te ilk derslerinin ağırlıklı olarak tabiî ilimler hakkında umuma açık bir şekilde yapılması da "fünûn" kelimesinin söz konusu ilimlere yönelik algılanmasını etkilediği göz önünde bulundurulmalıdır.

Fünûn kelimesinin kadim ilim, kültür ve eğitim tarihimizin teşekkül etmeye başladığı dönemlerden itibaren gündemde olan kullanışlı ve ilimlerin bütününü kapsayıcı anlamına rağmen 1279/1862'de çıkan bahsi geçen derginin, "fünûn" kelimesini dinî meselelerden ayırmak şeklindeki kavramlaştırması; diğer dergilerin fünûnu tabii ilimler ağırlıklı tanımlaması ve Dârulfünûn'daki konferansların tabiî ilimleri ön plana çıkarması gibi örneklerin bu tarihten günümüze kadarki dönemde "fünûn" kelimesinin, zihinlere sadece tabiî ilimleri kastedecek şekilde yerleşmesinde etkili olduğu düşünülebilir.

\section{"Dârulfünûn" Terkibi}

Bu açıklamalardan sonra hem "dâr" hem de "fünûn" kelimelerinin kapsamından ve kullanılış alanlarından hareketle Dârulfünûn terkibi ile kastedilenin ne olduğuna yakından bakmakta fayda bulunmaktadır. Dârulfünûn isminin gerek ortaya çıktığı arşiv belgelerinde gerekse bu ismin Osmanlı kamuoyuna ilan edildiği belgelerde yeni eğitim kurumu nasıl tanımlanmaktadır? Belgelere bakıldığında Dârulfünûn terkibindeki kavramların kadim tarihteki kullanıma uygun bir içerik zenginliğine sahip olduğu söylenebilir mi?

İlk mazbatalarda Dârulfünûn, mevcut mekteplerin ileri derecesi olarak takdim edilmektedir. Ülkenin bayındırlığını gerektirecek "ulûm ve fünûn-1 mütenevvia"nın menşei kabul edilen Dârulfünûn, terbiyet-i âmme meselesinin çözüm kaynağı olarak da görülmekte; yeni eğitim kurumunun devlete ve millete iyilikleri dokunacağı düşünülmektedir. Belgelerde "ulûm-1 mütenevvia mektebi" diye tavsif edilen Dârulfünûn, yukarıda verilen "fünûn" kelimesinin içeriğinin zenginliğine paralel olarak, tek bir ilim gurubundan ziyade çeşitli ilimlerin okutulduğu yüksek dereceli bir müessese şeklinde tanımlanmaktadır. ${ }^{90}$

Takvim-i Vekâyi'de Dârulfünûn'un ilan edildiği haberde ise kuruma yüklenen mühim görev; Osmanlı tebaasından kim olursa olsun insanî olgunluğunu tamamlamak isteyenler ile devlet makamında istihdam talebinde bulunanlar için bütün ilimlerin ve fenlerin tahsil edileceği bir merkez vazifesidir. ${ }^{91}$ Bunu teyit eden

89 Fen, 10 Mart 1327/21 Rabiülevvel 1329, numara 1.

90 İ.MSM, 25/657 lef 1. 9 Receb 1262/3 Temmuz 1846. Meclis-i Maârif-i Dâimî’nin Lâyihas1

91 Takvim-i Vekâyi, 27 Receb 1262/21 Temmuz 1846, sayı 303: 2, sütun 1. 
bir başka haberde de hâlihazırda mekteplerde öğretimi yapılan fünûn ve maârifin yanında bütün ulûm, maârif ve insanlığın yaratılışının tezyini için lüzumlu olan her türlü fünûnun bahsi geçen Dârulfünûn'da eğitim ve öğretiminin yapılacağ1 bildirilmektedir. ${ }^{92}$ Konuyla ilgili bir arşiv belgesinde ise Dârulfünûn, "tekmîl-i zât etmek isteyenler içün müntehâ-yı ulûmun meksebi” olarak yani ilimlerin ileri derecede tahsil edildiği bir yer şeklinde takdim edilmektedir. ${ }^{93}$

Dârulfünûn'un bu şekilde tanımlanması, Ortaçağ' daki belirli alanlarda uzmanlaşan üniversite anlayışından farklı bir şekle evrilen modern üniversite anlayışının mimarı Humboldt'un (1767-1835) "bütün bilimleri aynı çatı altında birleştirme şeklinde öne sürdüğü üniversite fikri” ile paralellik arz etmektedir. ${ }^{94} 1874$ 'te açılan Dârulfünûn-1 Sultan̂̂’nin müdürlüğünü yapan Sava Paşa da (1832-1904) "Dârulfünûn” manasına geldiğini söylediği “Üniversité” kelimesinin tarifini, insan aklının idrak edebileceği bilcümle malumatın talim ve taallüm ettirildiği mahal ${ }^{95}$ şeklinde yapmaktadır.

Dârulfünûn terkibinin ilk gündeme geldiği dönemde bütün ulûm ve fünûnun merkezi kabul edilmesi şeklindeki bakış açısı, bu kurumda eğitim öğretimin başladığı dönemlerde de devam ettirilmiştir. Dârulfünûn'da ilk eğitim 22 Receb 1279/13 Ocak 1863 'te umuma açık dersler (ders-i âm) şeklinde verilmeye başlanmıştır. Konferans mahiyetinde olan bu derslerin konuları tarih, coğrafya, fizik, kimya ve tabii bilimler ile alakalıdır. ${ }^{96}$ Konferanslar şeklinde geçen ilk eğitim öğretim tecrübesinin ardından 1869 yılında Dârulfünûn-1 Osmanî adı verilen kurum için bölümleşmenin olduğu ayrıntılı bir program hazırlanmıştır. Programda Dârulfünûn, üç şubeye bölünmüş ve her şubenin dersleri de ayrıntılı bir şekilde belirlenmiştir. Tablo 1'de verilen programın içeriğine bakıldığında bu eğitim kurumunun, "fünûn" kelimesinin tahlilinde değinildiği üzere, edebî ilimlerden ulûm-1 diniyeye; hikemî ilimlerden tabiî ilimlere; riyazî ilimlerden tarih ilimlerine kadar çok geniş bir yelpazedeki ilimlerin genelini kapsadığg görülmektedir.

92 Takvim-i Vekâyi, 11 Muharrem 1264/19 Aralık 1847, sayı 361: 3, sütun 2.

93 İ. DH, 129/6634 lef 2. 17 Şevval 1262/8 Ekim 1846.

94 Seyfi Kenan, "Üniversite”, DİA, (İstanbul, 2012), XL: 344. Bu bilgi şurada da tekrarlanmaktadır: Seyfi Kenan, "Modern Üniversitenin Oluşum Süreci”, Osmanlı Araştırmaları/The Journal of Ottoman Studies, XLV (2015), s. 353.

95 Sava Paşa, "Mukaddime”, Mekâtib-i Âliye-i Fenniye yani Dârulfünûn-ı Sultanî'nin Nizamnâme-i Dâhiliyesiyle Dürûs Cedvelidir. (La Türki Matbaasında tab olunmuştur, 1293) 4-5.

96 Mehmet Ali Aynî, Dârulfünûn Tarihi, Hazırlayan: Aykut Kazancıgil. (İstanbul: Kitabevi, 2007) 14; Osman Nuri Ergin, Türkiye Maarif Tarihi: İstanbul Mektepleri ve İlim, Terbiye ve Sanat Müesseseleri Dolayıslyla. (İstanbul: Eser Matbaası, 1977), C. I-II: 552; İhsanoğlu, "Darülfünûn Tarihçesine Giriş: İlk İki Teşebbüs”, 706-709. 
Tablo 1.

Darülfünûn-ı Osmanî'deki Şubeler ve Dersleri ${ }^{97}$

\begin{tabular}{|c|c|c|}
\hline $\begin{array}{c}\text { Ulûm-ı Tabiiyye ve Riyaziye } \\
\text { Şubesi }\end{array}$ & Hikmet ve Edebiyat Şubesi & İlm-i Hukuk Şubesi \\
\hline Heyet & Mantık & F1kh-1 Şerifin Muamelat Bahsi \\
\hline Hikmet-i Tabiiyye & Meâni & Usûl-i F1kıh \\
\hline İlm-i Kimya & Beyân & Romalıların Kanunu \\
\hline İlm-i Tabakâti'l-arz & İlm-i Kelâm & Hukuk-1 Milel \\
\hline $\begin{array}{l}\text { Tarih-i Ulûm-1 Tabiiyye ve } \\
\text { Riyaziye }\end{array}$ & İlm-i Aruz & $\begin{array}{l}\text { Hukuk-1 Âdiyeye Müteallik } \\
\text { Usûl-i Muhakeme }\end{array}$ \\
\hline İlm-i Nebâtât & Mükemmel Arabî & Ticaret-i Berriye ve Bahriye \\
\hline İlm-i Hayvanât & Fârisî & Ceza Kanunnâme-i Hümâyunları \\
\hline Hendese & Türkî & Usûl-i Muhakeme-i Cinayet \\
\hline Müsellesât & Fransizca & Hukuk-1 Mülkiye \\
\hline $\begin{array}{l}\text { Cerr-i Eskâlin Nazariyât ve } \\
\text { Tatbikatı }\end{array}$ & $\begin{array}{l}\text { Yunan ve Latin Lisanlarıyla Bilumum } \\
\text { Ümmehat-1 Elsine Kavâidinin Tatbik } \\
\text { ve Mukayesesine Dâir Sarf-1 Umûmî }\end{array}$ & $\begin{array}{l}\text { Fransızların Hukuk-1 Âdiye } \\
\text { Kanunnâmesi }\end{array}$ \\
\hline Hendese-i Resmiye & İlm-i Ahvâli'n-Nefs & \\
\hline Menâzır & İlm-i Ahlâk & \\
\hline İlm-i Maâdin & Hukûk-1 Tabiiye & \\
\hline Hendesenin Cebire Tatbiki & İlm-i Tarih & \\
\hline Hesab-1 Tefâzulî ve Tamamî & Tarih-i Umûmî & \\
\hline \multirow[t]{3}{*}{ Fenn-i Tahtît-i Arazî } & İlm-i Âsâr-1 Atika & \\
\hline & İlm-i Meskûkât & \\
\hline & İlm-i Terkib-i Vücûd-i İnsanî & \\
\hline
\end{tabular}

Yukarıdaki tabloda yer alan derslerden heyet, mantık, fikh-1 şerifin muamelat bahsi, hikmet-i tabiiyye, meânî, usûl-i fikıh, beyân, ilm-i kelâm, ilm-i aruz, fârisî, heyet, hendese, hesab gibi önemli bir kısmı medrese eğitim anlayışı çerçevesinde gelişen müfredatta da yer almaktadır. ${ }^{98}$ Dolayısıyla girişte bahsi geçtiği üzere Dârulfünûn'da okutulan derslerin medresede okutulanlarla bir ilgisinin bulunmadığını söylemek isabetli görünmemektedir. ${ }^{99}$

Dârulfünûn'un 1286/1870'deki ikinci kez açılışında konuşan devlet adamları da çeşitli ilimleri kastedecek şekilde meseleye yaklaşmaktadırlar. Dönemin Maârif-i Umûmiye Nâzırı Safvet Paşa (ö. 1815-1883), kendi zamanında ulûm ve fünûnun yayılması için açılan rüşdiye mektepleri ile Mekteb-i Sultanî gibi maârif alanındaki

97 Maârif-i Umûmiyye Nizamnâmesi (Matbaa-i Âmire, 1292), 81.-82. ve 83. Madde.

98 Medrese eğitim anlayışı çerçevesinde gelişen müfredat için bkz. XVIII. Asrın Ortalarına Kadar Türkiye'de İlim ve İlmiyeye Dâir Bir Eser: Kevâkib-i Seb'a Risalesi, s. 72-80; Cevat İzgi, Osmanlı Medreselerinde İlim: Riyazî İlimler (İstanbul: İz Yayıncılık, 1997), I: 69-116. Medrese müfredatı hakkında yayımlanmış literatür için bkz. Şükran Fazlığlu, "Osmanlı Medrese Müfredatına Dair Çalışmalar: Nereden Nereye?”, Türkiye Araştırmaları Literatür Dergisi, 2008, sayı 12, VI: 593-609.

99 İhsanoğlu şu şekilde ifade etmektedir: "Tanzimat ricalinin, bu yeni eğitim kurumunun medrese ve orada okutulan ilimlerle ilgisinin olmaması hususunda bir tereddüdü yoktu.” Bkz. İhsanoğlu, Dârülfünûn: Osmanlı'da Kültürel Modernleşmenin Odă̆ı, I: 79. 
olumlu gelişmeleri zikrettikten sonra meseleyi Dârulfünûn'a getirmiştir. ${ }^{100}$ İsmi sayılan orta seviyeli eğitim veren kurumları başarıyla tamamlayan öğrencilerden bir üst eğitim kurumuna geçecekler için Dârulfünûn'un tesis edildiğini bildirmiş ve kurumun tesisini şu şekilde ifade etmiştir:

“...tahsilât-1 vâkıa-i ilmiyye ve malumât-1 mütenevvia-i müktesebelerini bir kat daha ikmâl etmek isteyenler için dahî Dârulfünûn nâm ve unvanıyla bina ve inşâ olunup heyet-i vükelâ-i fihâm hazerâtının bizzat küşâd-1 resminin icrâsında bulundukları işbu medrese-i ilmiyenin tesisiyle tahkim-i esas-i medeniyet-i sahîhaya himmet buyurulmuştur..."101

Zikredilen kurum 1874 y1lında Dârulfünûn-1 Sultanî ismiyle de faaliyetini sürdürmüştür. Bu dönemdeki programında da Hukuk Mektebi, Turuk ve Meâbir Mektebi ile Edebiyat Mektebi şeklinde üç şube açılmıştır. Her üç şubenin dersleri edebiyattan tarihe, hukuktan riyaziyata kadar değişik alanları kapsamaktadır. ${ }^{102}$

Kısa süren bu iki tecrübenin ardından eğitim öğretime nihayetinde 1900 yılında Dârulfünûn-1 Şahne adı altında tekrar başlanmıştır. Bu dönemde açılan Dârulfünûn, Avrupa'daki üniversitelerde olduğu gibi beş şubeli (fakülteli) yüksek eğitim veren kurum hüviyetine kavuşmuştur. Yeni Dârulfünûn; Ulûm-1 Âliye-i Diniye, Edebiyat, Ulûm-1 Riyaziye ve Tabiiyye, Mekteb-i Hukuk ve Mekteb-i Tıbbiye-i Mülkiye'den oluşan beş şubeli bir yapıda kurulmuştur. ${ }^{103}$ Burada zikredilen beş farklı şube ve her şubedeki müstakil ilimlerin varlığı, Dârulfünûn'un 1846 yılındaki belgede ifade edilen "ulûm ve fünûn-1 mütenevvia"nın menşei olma şeklindeki tanımlamaya uygun bir eğitim kurumu haline geldiğinin kanıtı olmaktadır. Görüldüğü üzere Dârulfünûn, gerek 1869 ve 1874'teki ders programları olsun gerekse 1900'deki programı olsun sadece tabiî ilimlerin değil dinî, edebî, hikemî ilimler de dâhil bütün ilimlerin okutulduğu yüksek eğitim veren bir kurum olmuştur.

\section{Sonuç}

Osmanlı Devleti'nde XIX. yüzyllın ikinci çeyreğinde eğitim işlerinin “terbiyet-i âmme" kapsamında görüşülmesi ve bir takım planlamaların yapılması için Meclis-i Maârif-i Muvakkat kurulmuştur. Meclis, eğitim öğretim faaliyetlerinin üç kademeye

100 Takvim-i Vekâyi, 20 Zilkade 1286/21 Şubat 1870, say1 1192: 2.

101 Takvim-i Vekâyi, 20 Zilkade 1286/21 Şubat 1870, sayı 1192: 2, sütun 3.

102 Dârulfünûn-1 Sultanî’nin dersleri için bkz. Mekâtib-i Âliye-i Fenniye yani Dârulfünûn-ı Sultanî'nin Nizamnâme-i Dâhiliyesiyle Dürûs Cedvelidir (La Türkî Matbaasında tab olunmuştur, 1293), 47-50. Dârulfünûn-1 Sultanî hakkında geniş bilgi için bkz. Ekmeleddin İhsanoğlu, "Darülfünûn Tarihçesine Giriş: Üçüncü Teşebbüs Darülfünûn-1 Sultan̂̂”, Belleten (Ankara: Türk Tarih Kurumu Basimevi, 1993), LVII/218: 201-239.

103 Dârulfünûn-ı Şâhâne Nizamnâmesi (Dârulhilâfeti'l-Aliyye: Malumat Kütüphânesi, tâbi' ve nâşiri es-Seyyid Mehmet Tahir, 1318), ikinci madde. 
ayrılması ve o zamanki eğitim kurumlarının ileri derecesinde olmak üzere yüksek eğitim verecek yeni bir kurumun açılması gerektiği yönünde devlete tavsiyede bulunmuş ve kuruma "Dârulfünûn" ismini uygun görmüştür. Tarih sahnesine yeni çıkan yüksek eğitim verecek kurumun açılışının arka planında, gayrimüslim tebaanın eğitim öğretim faaliyetlerinin karşılanması için tesisi düşünülen bir "fünûn mektebi" bulunmaktadır. O dönemde reâyâ eğitim kurumlarının istenilen seviyede olmaması sebebiyle gayrimüslim tebaa çocuklarını Avrupa'ya göndermektedir. Çocukların orada zararlı şeyleri öğrenmelerinden dolayı ortaya devlet aleyhine sorun çıktı̆̆ tespiti yapılmaktadır. Bu sorunun önüne geçmek maksadıyla reayaya mahsus "riyazî ilimler, sanayi, sanatlar ve meslekler"in öğretiminin yapılacağı bir "fünûn mektebi”nin açılmasına ilişkin Padişah onayı alınmış ancak bu kurumun akıbeti muğlak kalmıştır. Fünûn mektebini açma işi kendisine verilen meclisin daha sonra "Dârulfünûn"un kurulması yönünde hazırladığı rapor Padişah tarafindan onaylanmıştır. Fünûn mektebinin aksine Dârulfünûn, "terbiyet-i âmme" kapsamında sadece gayrimüslim tebaaya değil fakat bütün Osmanlı tebaasına hitap edecek ve sadece belli bir ilim gurubunu değil fakat bütün ilimleri kapsayacak şekilde tasavvur edilmiştir.

Çalışmamızın neticesinde "Dârulfünûn" terkibini oluşturan kavramların kadim ilim, kültür ve eğitim tarihimizde karşılığının bulunduğu anlaşılmıştır. Tarihte ilim, kültür ve eğitim ile ilgili faaliyetlerin yapıldığı mekânı işaret etmek üzere "dâr" kelimesi ilk dönemlerden itibaren anahtar kavram olarak kullanılmıştır. "Fünûn" kelimesi de erken dönemden itibaren tek bir ilmi karşılamaktan ziyade edebî, lügavî, dinî, hikemî, riyazî, tabiî gibi ilimlerin bütününü ifade etmekte kullanılan bir kavram olmuştur.

Gerek Meclis-i Muvakkat'ın gerekse diğer yetkili makamların raporlarında "Dârulfünûn" terkibi, mevcut mekteplerin ileri derecesi; ülkenin bayındırlığını gerektirecek "ulûm ve fünûn-1 mütenevvia"nın menşei; Osmanlı tebaasından kim olursa olsun insanî olgunluğunu tamamlamak isteyenler ile devlet makamında istihdam talebinde bulunanlar için bütün ilimlerin ve fenlerin tahsil edileceği bir merkez; "tekmîl-i zât etmek isteyenler içün müntehâ-y1 ulûmun meksebi” olarak tanımlanmıştır.

Dârulfünûn'da eğitim öğretimin başladığı 1863’ten 1900'e kadar farklı dönemlerde oluşturulan ders programlarının, "fünûn" kelimesinin tahlilinde değinildiği üzere, edebî ilimlerden ulûm-1 diniyeye; hikemî ilimlerden tabiî ilimlere; riyazî ilimlerden tarih ilimlerine kadar çok geniş bir yelpazedeki ilimlerin genelini kapsadığı tespit edilmiş ve buradaki ilimlerden ulûm-1 diniye, ulûm-1 edebiye, mantık, hikmet, hesap, hendese, heyet ve benzerlerinin medrese eğitim anlayışında karşıllı̆ının bulunduğu dikkatlere sunulmuştur. 
Bütün bu açıklamalardan sonra görülmüştür ki "Dârulfünûn" şeklindeki terkip ne İslâm ilim, kültür ve eğitim tarihine uzak ne de Osmanlı Devleti'ndeki mevcut eğitim anlayış1 ile örtüşmeyen bir isimlendirmedir. Böylesine bir terkibin seçilmesi elbette farklı bir oluşuma işaret etmek içindir. Ancak bu yapılırken medreseye ve burada okutulan ilimlere bir karşı çıkış ya da onları reddetme şeklinde bir tavır olmamıştır. Tarihten gelen birikim iyi bir şekilde değerlendirilerek bu isimlendirme yapılmıştır. İlimler tasnifinin yapıldığı kitaplarda görüldüğü üzere "fünûn" kelimesinin dinî, edebî ve tabiî gibi bir ayırım yapılmadan ve belli bir ilim gurubuna hasredilmeden ilimlerin genelini kuşatıcı anlam genişliği, yeni kurulacak olan yüksek eğitim veren kurumdaki ilimlerin çeşitliliği ile irtibatlandırılmıştır. Zira bu durum Dârulfünûn fikrinin ve isimlendirilmesinin gündeme geldiği Meclis-i Maârif-i Muvakkat'ın Meclis-i Vâlâ'ya sunulan layihasında da sarih bir şekilde görülmektedir. Lahiyada geçen "Dârulfünûn" terkibi "kâffe-i ulûm ve fünûn"un okutulacağı bir mekâna ve oluşuma işaret etmektedir. Bu bağlamda çalışmamızda Dârulfünûn terkibindeki unsurların kadim ilim, kültür ve eğitim tarihinde bir karşılı̆̆ının bulunduğu; yeni yapının medrese ve onun temsil ettiği eğitim anlayışının karşısında olmadığı; terkipteki fünûn kelimesinin sadece Batı kaynaklı bilimler için değil aynı zamanda ulûm-1 Arabiye, edebiye, mantık, ulûm-1 diniye ve hikmet gibi ilimleri de içine alacak şekilde kullanıldığ 1 anlaşılmıştır.

Hakem Değerlendirmesi: Dış bağımsız.

Çıkar Çatışması: Yazar çıkar çatışması bildirmemiştir.

Finansal Destek: Yazar bu çalışma için finansal destek almadığını beyan etmiştir.

Peer-review: Externally peer-reviewed.

Conflict of Interest: The author has no conflict of interest to declare.

Grant Support: The author declared that this study has received no financial support.

\section{Kaynakça/References}

\section{Başbakanlık Osmanlı ve Meşihat Arşivi Belgeleri}

AMD-d. (Amedî Kalemi Defterleri), 374/17-18.

HR.TH. (Hâriciye Nezâreti Tahrirât), 33/13.

İ.DH. (İrâde Dâhiliye), 129/6634; 113/5710; 99/4972.

İ.MSM. (İrâde Mesâil-i Mühimme), 03/46; 12/519; 13/276; 25/653; 25/654; 25/656; 25/657; 25/669; $29 / 807$.

İST. MFT. MSH. DFT. 3/1999

MF.MKT. (Maârif Nezâreti Mektûbî Kalemi), 65/37

MVL.d. (Meclis-i Vâlâ Defterleri), 470/10.

C.AS. (Cevdet Askeriye), 839/35813. 
C.MF. (Cevdet Maârif), 1/31.

Y.A.RES. (Yıldız Resmî Maruzat), 81/60.

\section{Gazeteler}

Takvim-i Vekâyi’, 280; 283; 303; 361; 362; 427; 567; 1192, 1570.

\section{İkincil Kaynaklar}

Adıvar, Abdülhak Adnan. Osmanlı Türklerinde İlim. İstanbul: Maarif Matbaası, 1943.

Akyıldız, Ali. Tanzimat Dönemi Osmanlı Merkez Teşkilâtında Reform. İstanbul: Eren Yayıncılık, 1993.

Albayrak, Sadık. "Dârü'l-Hikmeti'l-İslâmiyye”, DİA. İstanbul, 1993. VIII: 506-507.

Aynî, Mehmet Ali. Dârulfünûn Tarihi. Hazırlayan: Aykut Kazancıgil. İstanbul: Kitabevi, 2007.

Berkes, Niyazi. Türkiye'de Çağdaşlaşma. İstanbul: Doğu-Batı Yayınları, tarih yok.

Bozkurt, Nebi. "Dârulkurrâ”, DİA. İstanbul, 1993. VIII: 543-545.

Bozkurt, Nebi. "Dârülhadis", DİA. İstanbul, 1993. VIII: 527-529.

Çankaya, Mücellitoğlu Ali. Mülkiye Tarihi ve Mülkiyeliler 1859-1949. Ankara: Örnek Matbaası, 1954.

Dârulfünûn-ı Şâhâne Nizamnâmesi. Dârulhilâfeti'l-Aliyye: Malumat Kütüphânesi, tâbi' ve nâşiri es-Seyyid Mehmet Tahir, 1318.

Doğan, İsmail. “Osmanlı Bilimsel Topluluklarının Türkiye'deki Bilim Eğitimine Etkileri”, Ankara Üniversitesi Ĕgitim Bilimleri Fakültesi Dergisi. 1993, XXVI/1: 131-149.

Engelhard, E. Türkiye ve Tanzimât: Devlet-i Osmaniye'nin Tarih-i Islahâtı 1826-1882. Mütercimi: Ali Reşâd. İstanbul: Kanaat Kütüphanesi, 1327.

Ergin, Osman Nuri. Türkiye Maarif Tarihi: Istanbul Mektepleri ve Ilim, Terbiye ve Sanat Müesseseleri Dolaylsiyla. İstanbul: Eser Matbaas1, 1977, C. I-II.

Erünsal, İsmail E. "Dârülilim”, DİA. İstanbul, 1993. VIII: 539-541.

Erünsal, İsmail E. "Dârülkütüb”, DİA. İstanbul, 2003. XXVII: 11-32.

Fazlığlu, Şükran. “Osmanlı Medrese Müfredatına Dair Çalışmalar: Nereden Nereye?”, Türkiye Araştırmaları Literatür Dergisi. 2008, sayı 12, VI: 593-609.

Fen. 10 Mart 1327/21 Rabiülevvel 1329, numara 1.

Firuzabadi, Ebü't-Tahir Mecdüddin Muhammed b. Yakub b. Muhammed. el-Okyanusü'l-Basit fi Tercümeti Kamusü'l-Muhit (Kamus Tercümesi). Tercüme: Mütercim Asım Efendi. İstanbul: Matbaa-i Osmaniye, 1305.

Fünûn. Âsar-1 Müteaddide-i Cedideden Mütercem. Mütercimi: M. Ali. İstanbul: Şirket-i Mertebiye Matbaas1, 1308. Birinci Cüz.

Hasebe, Kiyohiko. "An Ottoman Attempt for the Control of Christian Education: Plan of Fünûn Mektebi (School of Sciences) in the Early Tanzimat Period". Osmanlı Araştırmalar/The Journal of Ottoman Studies. XLI (2013), 231-251.

İbn Akîl, Ebü’l-Vefa Ali b. Akîl b. Muhammed el-Bağdadi. Kitâbü 'l-Fünûn. Tahkik: George Makdisi. Beyrut: Dârü'l-Maşrık, 1970.

İbn Akîl, Ebü'l-Vefa Ali b. Akîl b. Muhammed el-Bağdadi. Zehrü'l-Ğusûn min Kitâbi'l-Fünûn. Tahkik: Kamil Muhammed Harrât. Dımaşk: Dârü’t-Tevfik, 1420/1999. 
İbn Manzur, Ebü'l-Fazl Muhammed b. Mükerrem b. Ali el-Ensârî. Lisanü'l-Arab. Hazırlayan: Emin Muhammed Abdülvehhab-Muhammed es-Sadık el-Ubeydi. Beyrut: Dârü'l-ihyâi't-Türasi'l-Arabî, $1417 / 1997$.

İbnü'l-Arabî, Ebû Abdullah Muhyiddin Muhammed b. Ali. Şücûnü'l-Mescûn ve Fünûnü'l-Meftûn. Tahkik: Ali İbrâhim Kürdi. Dımaşk: Dâru Sa’deddin, 1419/1999.

İhsanoğlu, Ekmeleddin. "Darülfünûn Tarihçesine Giriş: İlk İki Teşebbüs”, Belleten. Ankara: Türk Tarih Kurumu Basımevi, 1990. LIV/210: 699-745.

İhsanoğlu, Ekmeleddin. “Tanzimat Döneminde İstanbul'da Dârulfünûn Kurma Teşebbüsleri”, 150. Yılında Tanzimat. Yayına Hazırlayan: Hakkı Dursun Yıldız. Ankara: Türk Tarih Kurumu Yayınları, 1992. 397-439.

İhsanoğlu, Ekmeleddin. "Darülfünûn Tarihçesine Giriş: Üçüncü Teşebbüs Darülfünûn-1 Sultan̂̂”, Belleten. Ankara: Türk Tarih Kurumu Basımevi, 1993. LVII/218: 201-239.

İhsanoğlu, Ekmeleddin. "Dârulfünûn: Mefhum ve Müessese Olarak Sultan II. Abdülhamid Dönemine Kadar Gelişmesi”, Sultan II. Abdülhamid ve Devri Semineri: 27-29 Mayıs 1992 Bildiriler. İstanbul: Edebiyat Fakültesi Basımevi, 1994. 173-190.

İhsanoğlu, Ekmeleddin. Dârülfünûn: Osmanlı'da Kültürel Modernleşmenin Odağı. İstanbul: İslâm Tarih, Sanat ve Kültür Araştırma Merkezi, 2010. I.

İhsanoğlu, Ekmeleddin. "Cem“iyyet-i İlmiyye-i Osmâniyye”, TDV İslâm Ansiklopedisi. https:// islamansiklopedisi.org.tr/cemiyyet-i-ilmiyye-i-osmaniyye (29.10.2019).

İsmail Hakk1. Maârifde Bir Siyaset. İstanbul: Necm-i İstikbâl Matbaası, 1335.

İzgi, Cevat. Osmanlı Medreselerinde İlim: Riyaẑ́ İlimler. İstanbul: İz Yayıncılık, 1997. I.

Kâsımî, Cemaleddin Muhammed b. Muhammed Saîd Cemaleddin. Kavâidü t-Tahdis min Fünûni Mustalahi'l-Hadis. Dımaşk: Matbaatu İbn Zeydun, tarih yok.

Katib Çelebi, Hacı Halife Mustafa b. Abdullah. Keşfü'z-Zünûn an Esâmi'l-Kütüb ve 'l-Fünûn. Tashih:

M. Şerefettin Yaltkaya, Kilisli Rifat Bilge. Ankara: Milli Eğitim Bakanlığı, 1941.

Kaya, Mahmud. "Beytülhikme”, DİA. İstanbul, 1992. VI: 88-90.

Kaya, Mahmut. "Dârülhikme”, DİA. İstanbul, 1993. VIII: 537-538.

Kaya, Mahmut. "Sipâhîzâde Mehmed”, DIA. İstanbul: 2009. XXXVII: 258-259.

Kenan, Seyfi. "Üniversite”, DİA. İstanbul: 2012. XL: 338-348.

Kenan, Seyfi. "Modern Üniversitenin Oluşum Süreci”, Osmanlı Araştırmaları/The Journal of Ottoman Studies, 2015. XLV: 333-367.

Köksal, Asım. "Dârülerkam", DİA. İstanbul, 1993. VIII: 520-521.

Kudâî, Ebu Abdullah Muhammed b. Selâme b. Ca'fer. Tarihü'l-Kudâî: Kitâbü Uyûni'l-Maârif ve Fünûni Ahbâri'l-Halâif. Tahkik: Cemil Abdullah Muhammed el-Misrî. Mekke: Câmiatü Ümmi'lKurâ, 1415/1995.

Kûfî, Ebû Ca'fer Muhammed b. Süleyman. Kitâbü'l-Müntehab ve yelîhi Kitâbü'l-Fünûn. San'a: Dârü'l-Hikmeti'l-Yemaniyye, 1993.

Kut, Turgut. "Dâruttıbâa", DİA. İstanbul, 1994. IX: 10-11.

Kutluer, İlhan. "İlim”, DIA. İstanbul, 2000. XXII: 109-114.

Kütükoğlu, Mübahat S. “Dârü'l-Hilâfeti'l-Aliyye Medresesi”, DİA. İstanbul, 1993. VIII: 507-508. Mâ̂rif-i Umûmiyye Nizamnâmesi. Matbaa-i Âmire, 1292. 
Mahmud Cevad, İbnü'ş-Şeyh Nâfi. Maârif-i Umûmiye Nezâreti Tarihçe-i Teşkilat ve İcraatı. Matbaa-i Amire, 1338.

Mekâtib-i Âliye-i Fenniye yani Dârulfünûn-ı Sultanî'nin Nizamnâme-i Dâhiliyesiyle Dürûs Cedvelidir. La Türkî Matbaasında tab olunmuştur, 1293.

Mekteb-i Sultani Tevzi-i Mükâfat Cedvelidir. Kostantiniye: Matbaa-i Ebuzziyâ, 1301.

Mekteb-i Sultani Ders Programıdır. İstanbul: Âlim Matbaası, 1316.

Münif Efendi: "Mukaddime”, Мecmua-i Fünûn. İstanbul, 1279., Numara 1.

Nakkaş, Ebû Saîd Muhammed Ali b. Amr b. Mehdi el-Hanbeli. Fünûnü'l-Acâib. Tahkik: Mustafa Abdülkadir Ata. Beyrut: Müessesetü'l-Kütübi’s-Sekafiye, 1990.

Nev’̂̂, Yahya. İlimlerin Özü (Netâyicü'l-Fünûn). Hazırlayan: Ömer Tolgay. İstanbul: İnsan Yayınları, 1995.

Nüveyri, Şehabeddin Ahmed b. Abdülvehhab b. Muhammed. Nihâyetü'l-Ereb fì Fünûni'l-Edeb. Kâhire: Vizâretü's-Sekâfe ve'l-İrşâd, tarih yok.

Özcan, Azmi. “ Dârülulûm”, DİA. İstanbul, 1993. VIII: 553-555.

Öztürk, Cemil. "Dârülmuallimîn”, DİA. İstanbul, 1993. VIII: 551-552.

Saçaklızâde, Şeyh Muhammed bin Ebî Bekr el-Mer'aşî eş-Şehîr bi. Tertîbü'l-Ulûm. Tahkik: Muhammed b. İsmail es-Seyyid Ahmed. Beyrut: Dârü'l-Beşâiri'l-İslâmiyye, 1988.

Said Paşa 'nın Hatıratı. Dersaâdet: Sabah Matbaas, 1328. I.

Sarı, Nil. "Mekteb-i T1bbiyye”, DİA. İstanbul, 2004. XXIX: 2-5.

Salnâme-i Nezaret-i Mâ̂rif-i Umûmiyye. Matbaa-i Âmire, 1316. 1. Sene.

Sava Paşa, "Mukaddime", Mekâtib-i Âliye-i Fenniye yani Dârulfünûn-1 Sultanî’nin Nizamnâme-i Dâhiliyesiyle Dürûs Cedvelidir, La Türki Matbaasında tab olunmuştur, 1293.

Şentürk, M. Hüdai. "Dârülmaârif”, DİA. İstanbul, 1993. VIII: 548-549.

Tehânevî, Muhammed b. A'lâ b. Ali el-Faruki el-Hanefi. Keşşâfu Istılâhâti 'l-Fünûn. Haşiye: Ahmed Hasan Besic. Beyrut: Dârü'l-Kütübi'l-İlmiyye, 1418/1998. I.

Uçman, Abdullah. "Mecmûa-i Fünûn”, TDV İslâm Ansiklopedisi. https://islamansiklopedisi.org.tr/ mecmua-i-funun (29.10.2019).

Unat, Faik Reşit. Türkiye Eğitim Sisteminin Gelişmesine Tarihi Bir Bakış. Ankara: Milli Eğitim Basımevi, 1964.

Vankulu, Mehmed Efendi Vani. Lugat-ı Vankulu: Tercüme-i Sihah-ı Cevheri. Kostantiniye: Dârü'tTibâati'l-Cedîdeti'l-Ma'mûre, 1218/1803. II.

XVIII. Asrın Ortalarına Kadar Türkiye'de İlim ve İlmiyeye Dâir Bir Eser: Kevâkib-i Seb'a Risalesi. Metni yeni harflere ve ekinde Fransızca metinleri Türkçeye Çeviren: Nasuhi Ünal Karaarslan. Ankara: Türk Tarih Kurumu, 2015.

Zengin, Zeki Salih. Medreseden Dârulfünûna Türkiye'de Yüksek Din Eğitimi. İstanbul: Çamlıca Yayınları, 2011. 
